\title{
PARKO PROBLEMATIKA STRUKTŪRINĖJE MIESTO PLĖTROJE (ŠIAULIŲ MIESTO PAVYZDŽIU)
}

\author{
Inesa Alistratovaitė-Kurtinaitienè \\ Urbanistikos katedra, Vilniaus Gedimino technikos universitetas, \\ Pylimo g. 26/Trakug. 1, 01132 Vilnius, Lietuva \\ El.paštas: inesa.al@gmail.com; urbkat@vgtu.lt \\ Iteikta 2010-10-11
}

\begin{abstract}
Santrauka. Šiuo metu vẻl pradèta gręžtis ị miestuose esančius parkus kaip gyventojų poilsio, ramybės bei savotiškos atsvaros urbanizaciniams procesams oazes. Straipsnyje apžvelgiami miestų parkų urbanizuotoje aplinkoje ypatumai, pateikiama išskirtų parkų lyginamoji charakteristika, apžvelgiama Lietuvos miesto parkų evoliucija XX a. Šios informacijos fone pristatoma Šiaulių miesto centrinio parko galimybių studija, kurioje iškeltas uždavinys nuosaikiai urbanizuojant teritoriją aiškiai išskirti parko ribas bei kaip nepakenkti esančiam parkui integruoti urbanizacinį kaimyną, kartu pagerinant paties parko kompoziciją bei paslaugų infrastruktūrą. Pateikiama parko teritorijos analizė kaip urbanistinès struktūros elemento tyrimas: miesto gamtiniame karkase ir žaliujjų plotų sistemoje; žaliosios erdvès rangas bendrojoje miesto struktūroje (urbanistinès struktūros elementų vertybinè hierarchija), jos integracijos laipsnis; parko teritorijos transformacijos; esamos padèties analizè bei siūlymai.
\end{abstract}

Reikšminiai žodžiai: Šiaulių centrinis miesto parkas, urbanizuota aplinka, gamtinis karkasas, urbanistinè struktūra, erdvių hierarchija.

\section{Ivadas}

Miesto parkai intensyviai urbanizuotose teritorijose atlieka pauzių vaidmeni, turi itakos miesto ekologinei būklei bei žmogaus aplinkos higieninei kokybei, pagaliau formuoja miesto įvaizdị ir jo estetiką. Šių dienų problema - parkai nyksta, jų teritorijos mažèja, nes miesto centre urbanizacija veržiasi ne tik $\mathfrak{i}$ apleistas ir konversines teritorijas, bet pretenduoja ir ị jaukius viešosiomis erdvèmis tapusius parkus. Jų apsauga bei reglamentavimas nèra pakankamas (Dringelis 2001, 2003), dèl to brovimasis ị juos vyksta pažeidinèjant viešąji interesą.

Miesto parkai dažnai yra integruojami ị miesto žaliąją struktūrą, todèl svarbus klausimas yra tinkamas miestų žaliosios aplinkos elementų klasifikavimas, nes tam tikra žaliosios aplinkos kategorija skiriasi tvarkymo bei administravimo programomis (Dringelis 2005). Šiuo metu urbanistinis teritorijų planavimas yra glaudžiai susijęs su juridinio kai kurių teritorijų ir žemés sklypų statuso apibrèžimu - t. y. su tikslinès žemès naudojimo paskirties nustatymu, tai neabejotinai komplikuoja terminų (želdynai, žalioji aplinka ir pan.) vartojimą (Jakovlevas-Mateckis, Dringelis, Dimindavičiūtè 2007).

Kadangi priežastis yra naujų sklypų formavimas ar atsiradimas viešosiose erdvèse, urbanizavimo laipsnio nustatymas yra tik to pasekmé. Stebint parkų tyrimus, atliekamus Vakarų pasaulyje, išryškẻja tai, kad tikslinant ir reglamentuojant parko ribas nuosaiki urbanizacija juose vis tik yra itmanoma (Corner 2007; Project... 2010; Steenbergen, Reh 2003; Peter... 2010). Šiuo metu daugiausia inicijuojamas skirtingo lygmens (valstybinio, regioninio, nacionalinio ir t. t.) parkų ribų tikslinimas (korektūra) siekiant apsaugoti istoriškai susiformavusị ne tik patị kraštovaizdị (makromasteliu - t. y. valstybès, apskrities, aglomeracijos ir pan.), bet ir jo elementus (mikromasteliu - t. y. miesto, rajono, urbanistinio komplekso ir pan.) nuo neigiamo ūkinès veiklos poveikio, užtikrinant bendrąją ekologinę pu- 
siausvyrą (Lietuvos... 2010; Trakų... 2007; Krekenavos... 2009). Ši iniciatyva yra būtina norint tinkamai sureguliuoti veiklą, sudaryti prielaidas efektyviai saugoti ir tvarkyti šias teritorijas ypač po žemès restitucijos, kuri turèjo įtakos skirtingų lygmenų parkų priežiūrai ir administravimui. Nustatytos naujos ribos leis geriau organizuoti teritorijų lankymą, patenkinti rekreacinius visuomenès poreikius, sudaryti sąlygas turizmui plètoti.

Miestų parkai Lietuvoje taip pat nèra išimtis - parkų prieigų urbanizavimas kartais iš esmès koreguoja parko ribas. Vienas tokių parkų yra Šiaulių miesto centrineje dalyje. Ir nors tiek privatus sektorius, tiek savivalda yra suinteresuoti parko gyvavimo perspektyva, kliūtys tam vis tik egzistuoja, jas kuria Šiaulių miesto privataus sektoriaus konkurentai, kuriuos savivaldos organai ne visada pajègūs suvaldyti.

Tiek privataus sektoriaus, tiek savivaldos iniciatyva prieš $2 \mathrm{~m}$. buvo rengta galimybių studija teritorijai tarp Žemaitès g., Dobilo g. ir miesto centrinio parko (Alistratovaite et al 2007a, 2008). Keliamas tikslas kaip nepakenkti esančiam parkui, integruojant esamą (sovietinių metų pasekmè) ar numatomą (šių dienų privati iniciatyva) urbanizacinį kaimyną, kartu gerinant miesto parko kompoziciją bei paslaugų infrastruktūrą, taip pat tikslinant parko ribas. Laiko faktorius nagrinejjamas ịvairių transformacijų ir deformacijų tyrimų etape. Transformacijos ir deformacijos nèra traktuojamos kaip atitolimas nuo pirmapradès natūralios gamtos, nes miesto parkas (o ypač esantis centrinèje dalyje) traktuojamas ne tik kaip kraštovaizdžio elementas, bet ir kaip miestovaizdžio elementas.

\section{Miesto parku evoliucija XX a. Lietuvoje}

Peržvelgus Lietuvos miestų centrinèse dalyse esančiu parkų evoliuciją, matoma didelè intervencija ị šias neurbanizuotas teritorijas, kurios laikomos tiek rekreacine erdve, tiek gamtine miesto vertybe (1 pav.). Radikaliausiu parkų naikinimo laikotarpiu neabejotinai ịvardinamas XX a., kurị sąlygiškai galima būtu

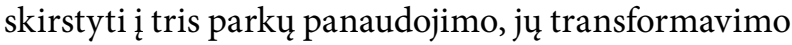
ir deformavimo etapus (etapai atitinka istorinius ir politinius lūžius):

- Nepriklausomos Lietuvos laikotarpis - iki 1940 m.;

- Sovietinių metų laikotarpis - nuo 1945 iki 1990 m.;

- Nepriklausomybę atgavusios Lietuvos laikotarpis nuo 1990 m. iki dabar.

$\mathrm{XX}$ a. pr. parkai atliko išimtinai vien rekreacinių teritorijų vaidmeni, nes tuo metu buvo daug mažesnè urbanizacija, o jų kultūrinimo procesai buvo nuosaikūs ir griežtai reglamentuoti.
Sovietiniais metais tipiniai visuomeninès paskirties statiniai (mokymo, mokslo įstaigos) želdynų teritorijose buvo statomi dèl ekologinių sąlygų, o statinius, susijusius su pramonine gamyba, stengtasi dislokuoti toliau nuo gyvenamųjų teritorijų, dèl to neretai tokios paskirties teritorijos atsidurdavo greta didesnių želdynų, jų pakraščiuose. Parkai tapdavo apsaugine teritorija tarp gyvenamųjų zonų ir pramonès. Ypač joje vyraudavo pastatai, neestetiški savo tūriais, o proporcija disonuojantys su psichologinę ramybę teikiančia vieta. Pramonè kaip urbanizuota ląstelè buvo kiek labiau izoliuojama parkais nuo kitų funkcinių zonų. Tokie faktoriai kaip privačios nuosavybès nebuvimas ar menka išskirtinų teritorijų apsauga buvo pagrindinè priežastis laisvo planavimo objektams rastis, o tuometinis supratimas apie socialinès būklès gerinimą, modernizavimą ir naujų darbo vietų kūrimą tapo prioritetu prieš istoriniu bei kultūriniu požiūriu vertingas teritorijas.

Po 1990-ųjų m. nepriklausomos Lietuvos laikotarpiu privatus kapitalas uzurpuoja viešąsias rekreacines erdves. Tam sąlygas sukūrè žemės reforma, jos grąžinimo bei privatizavimo procesai. Jais ignoruojamas viešasis interesas - vietoje urbanistinių koncepcijų įsivyrauja žemètvarkinis teritorijų skirstymas sklypais, viešo naudojimo teritorijos nèra apsaugotos nuo jų privatizavimo. Nors tokios teritorijos ir būna įteisintos kaip bendro naudojimo, tačiau vis tiek traktuojamos kaip laisvos ir neužimtos, tai neapsaugo jų nuo išskirstymo sklypais ir privatizavimo.

Ir tik maždaug nuo $2000 \mathrm{~m}$., kai technologiniai ir socialiniai perversmai jau kiek įsisiūbavo ir nulèmé naujos kokybès visuomenès atsiradimą, dèmesys po netrumpos pertraukos vèl buvo skiriamas gyvenamosios aplinkos kokybei, gamtinio potencialo regeneracijai, savojo miesto istorijai ir savotiškai miesto genetikai. Šiuo metu vèl pradèta gręžtis ị miestuose esančius parkus kaip gyventojų poilsio, ramybės bei savotiškos atsvaros urbanizaciniams procesams oazes. Jie tampa aplinkinių gyvenamųjų kvartalų viešąja rekreacine erdve, ypač tie parkai, kurie nera miestų pakraščiuose, o atvirkščiai miesto centrineje dalyje ar integruoti i gyvenamosios struktūros aplinką. Todèl daugelyje miestų atsiranda poreikis panagrinèti parką kaip sudètinę urbanistinès struktūros dalį reabilituojant rekreacinę funkciją, kartu tikslinant parko ribas.

\section{Miestų parkai urbanizuotoje aplinkoje}

Pasaulinio garso parkai ir kartu didieji miesto parkai (Londono Hyde Park 250 ha, Paryžiaus Bois de Boulogne 865 ha, Niujorko Central Park 337,2 ha ir Amsterdamo Bos Park $\sim 800$ ha) įkūnija tai, kas 
a)

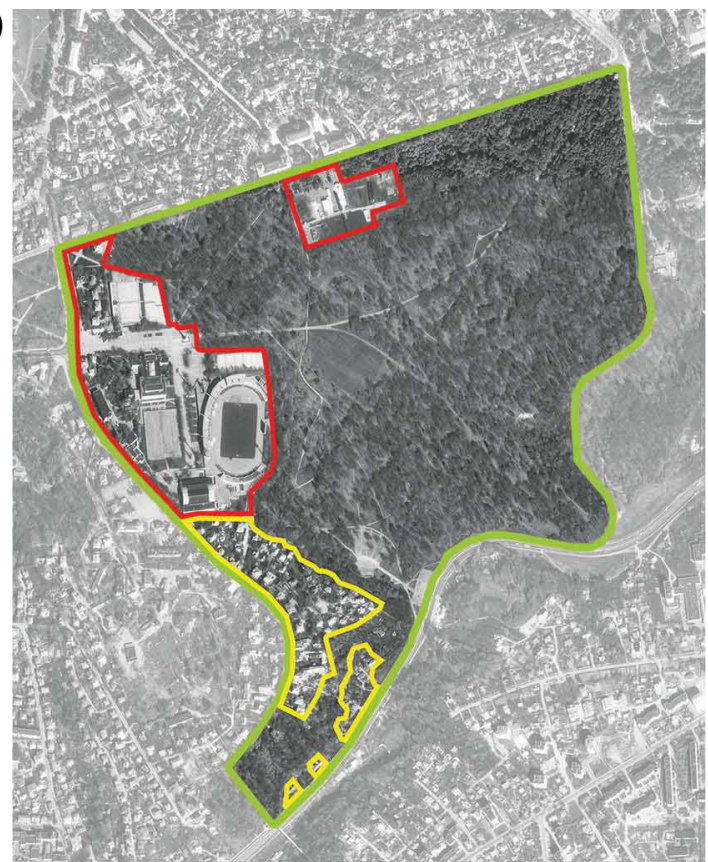

c)

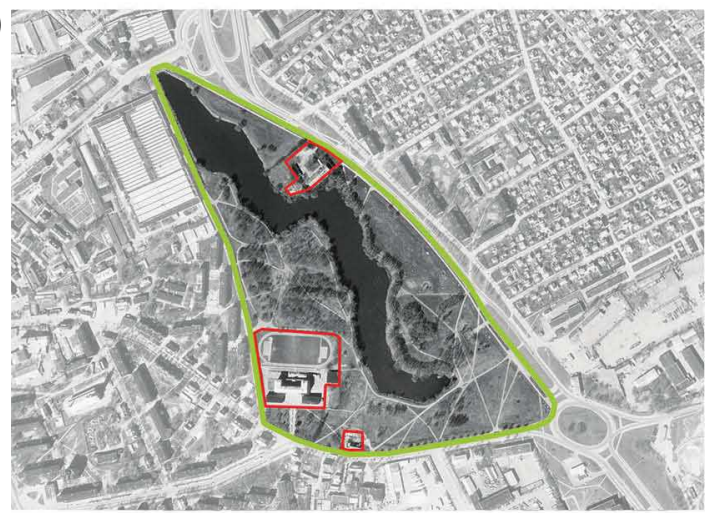

e)

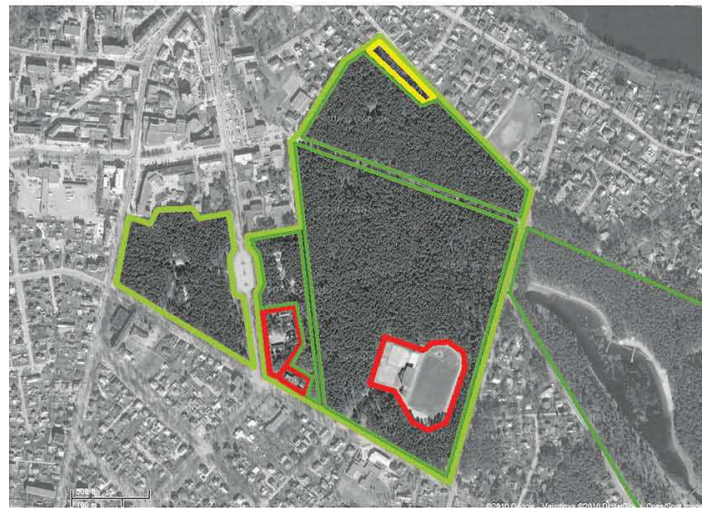

b)

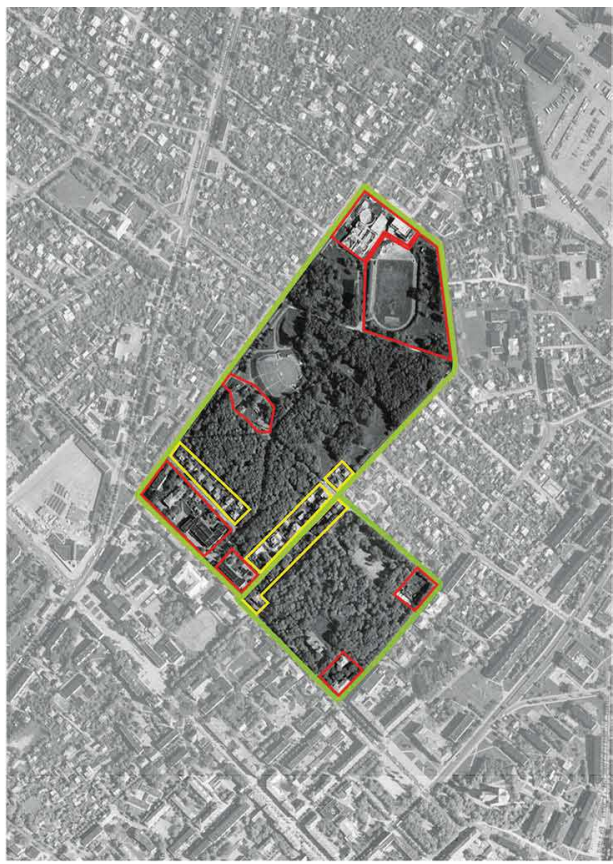

d)

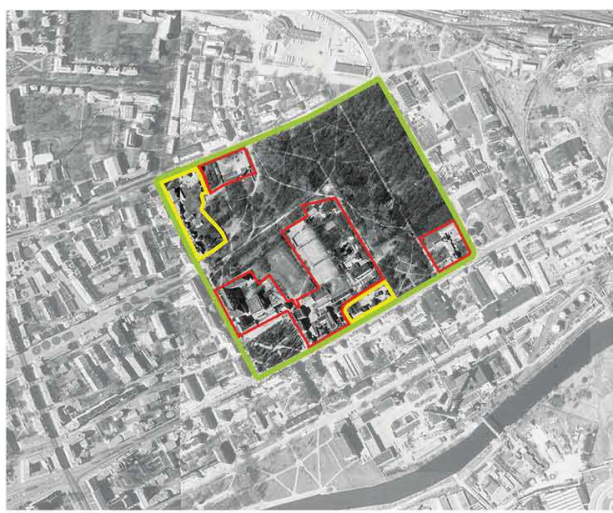

f)

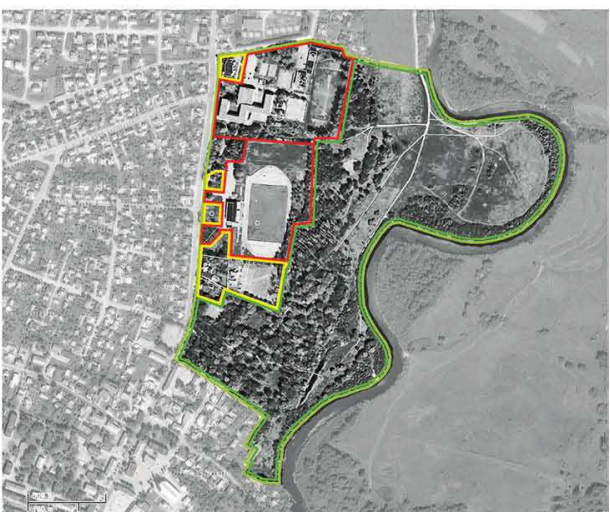

1 pav. Intervencijos į miestụ parkus mastas: a - Kaunas - Žaliakalnio parkas, b - Šiauliai - miesto centrinis parkas, c - Klaipèda - Trinyčiu parkas, d - Klaipèda - Skulptūru parkas, e - Alytus - miesto sodas ir parkas, $\mathrm{f}$ - Gargždai - miesto parkas. Žalia spalva - parko teritorija, raudona spalva intervencija i parku zoną užstatant visuomeniniais objektais daugiausia sovietiniais metais, geltona spalva - intervencija i parkų zoną užstatant privačiais gyvenamaisiais namais

Fig. 1. Degree of intervention into city parks. Green color - territory of park, red color - intervention into park zone by public objects in soviet time, yellow color - intervention into park zone by private residential house 
daugeliui žmonių yra svarbiausios tokio tipo vietovių vertybès - visuminis empirinių pojūčių spektras, konsoliduotas visuomeniškumas ir gyvenimas po atviru dangumi. Dideliuose parkuose tampa įmanoma gausybè socialinès veiklos formų, kurios šiuolaikiniame greitai kintančiame pasaulyje padeda formuoti bendruomeniškumą ir pilietiškumą. Anot parkų tyrejju J. Corner, J. Czerniak, G. Hargreaves, rašančių ne tik apie ekologinę urbanistiką, bet ir apie žaliąją miestų infrastruktūrą, parkų fizinis dydis suteikia galimybę juose eksponuoti ir stebèti stulbinančius elementus kintančias oro sąlygas, geologines struktūras, horizonto platybes ir augmeniją. Be jų patirtinio ir kultūrinio poveikio, didieji parkai taip pat vertinami dèl savo ekologinių funkcijų - didžiuosius parkus galima vadinti „žaliaisiais plaučiais“, kurie apvalo, gaivina ir turtina gyvenimą urbanizuotose vietovèse.

Šiandien dauguma dideliais užmojais paremtų miestų planavimo iniciatyvų pasaulyje sujungia intensyvaus užstatymo elementus su naujai kuriamų atvirų žaliųjų erdvių ruožais. Iš dalies šios atviros erdvès yra būdas ir priemonè kompensuoti dèl urbanizacijos mažejančius natūralius gamtos plotus.

Šią didelių parkų paklausą taip pat skatina visą pasauli apèmęs perèjimas nuo pramonės prie paslaugu ekonomikos, atlaisvinęs didelị kiekị anksčiau pramonei naudotų ir rezervuotų teritorijų. Šios teritorijos - senų ga myklų valdos, nebeveikiantys sąvartynai, išeikvoti karjerai, nebenaudojami uostai ir krantinès, buvę aerodromai ir netgi dèl žmonių migracijos ištuštèję miesto kvartalai ar ištisos jo zonos - yra patrauklios transformacijai į radikaliai naujas viešąsias erdves (parkus ar laisvalaikio zonas) (Corner 2007).

Nors didieji parkai suteikia daug džiaugsmo, erdvès ir kupini funkcijų, visgi jie kelia ir daug iššūkių. Jų projektavimas ir statyba yra gana brangūs. Šiais finansinių neramumų laikais parkų eksploatavimo išlaidos būna sumažinamos pirmiausia (tai galima matyti ir Lietuvoje - taupoma elektra, rečiau atnaujinama parko furnitūra, apkarpomas priežiūros biudžetas ir pan.). Dèl priežiūros stokos parkai greitai apleidžiami - jie tampa miesto "galiniu kiemu“, laukinio miestiškumo zona (čia atsiranda neteisèta veika, smurtas ir pan.).

Anot J. Czerniak, G. Hargreaves, šiandieniniai didieji parkai turi derintis prie ịvairialypès klientūros, paklusti gausybei kompromisiškų ar prieštaringų sprendimų. Dizaino, formos, išraiškos ir proceso organizavimo sumanymai bei idèjos greitai paklūsta valdymo, išlaikymo, kainos, saugumo ir programavimo reikalavimams. Todèl didžiųjų parkų projektuotojai turi nuosekliai ịrodyti, kaip dizainas, forma, išraiška ir procesas taikosi prie kiekvienos iš anksčiau minètu kasdieniškų, bet neišvengiamų sąlygų ir jas peržengia.
Dèl šios priežasties (t. y. urbanizacijos laipsnio) parkai, esantys miesto centrineje dalyje, nèra natūrali gamta, todèl čia negali būti taikomi natūralios gamtos vertinimo kriterijai, nes ne tik kad yra per mažas plotas lyginant su visu miestu, bet ir jų aplinka yra daugiau ar mažiau antropogenizuota.

Organizacija „Viešųjų erdvių projektavimas“ (Projects for Public Spaces ${ }^{1}$ ) yra išskyrusi 10 pagrindinių sèkmingos viešosios erdvès bruožų, taikytinų visoms viešosioms erdvèms ${ }^{2}$, tarp jų ir parkams:

1) identitetas - viešųjų erdvių įvaizdžio sąsaja su šalia esančiu visuomeniniu statiniu ar kitu objektu ir pan.,

2) trauka - mažesnių atraktyvių funkcinių zonų buvimas (fontanai, skulptūros, lauko kavinukès ir pan.),

3) patogumai - stacionarus ar laikinas fizinis įrengimas (apšvietimas, suoliukai, šiukšlių dèžè ir pan.),

4) funkcinis lankstumas - naudojimo intensyvumas tiek paros, tiek savaitės, tiek metų laikų atžvilgiu,

5) sezoniškumas - vietovès adaptavimas keičiantis sezonams, švenčių proga (įvairi programa),

6) pasiekiamumas - svarbiausias gyvybingumo elementas yra žmonių srautas, didinantis viešosios erdvès populiarumą,

7) perimetras - aktyvios ir svetingos viešosios erdvès prieigos yra gyvybiškai svarbios efektyviai jos vidinès erdvès egzistencijai,

8) prieigos - į viešąją erdvę vedantys takai, gatvès ar gretimų statinių cokoliniai aukštai bei juose vystoma veikla tiesiogiai priklauso nuo viešosios erdvès (jos įtakos gretimoms teritorijoms),

9) administravimas - nuolatinè viešosios erdvès priežiūra užtikrina nuolatinị lankymąsi joje,

10) finansavimas - gera priežiūra ir efektyvus administravimas (pvz., turi būti specialiai sukurtos ir partnerystès principais paremtos viešosios organizacijos, siekiančios akumuliuoti ir papildyti administracines išlaidas iš tiesiogiai vykdomų ìvairiapusių veiklų).

Nepaisant šių 10 sėkmingos viešosios erdvės projektavimo bruožų, miesto parko patrauklumas, jo vitališkumas miestiečių gyvenime yra iššūkis šio šimtmečio kraštovaizdžio architektūros projektavimui ir lakesnei visuomenès vaizduotei.

Toliau aiškinantis bendrines miestų parkų problemas, kai kurias miestų parkų, esančių urbanizuotoje

\footnotetext{
[interaktyvus] [žiūrèta $2010 \mathrm{~m}$. sausio 20 d.]. Prieiga per internetą: <www.pps.org>.

2 Viešosios erdvès pagal PPS yra parkai, judejjimo infrastruktūra (transportation), turgūs, senamiesčiai, bendruomenès centrai, mokslo bei švietimo ịstaigų teritorijos, aikštess, krantinès ir pan.
} 
aplinkoje, raidos tendencijas ir aktualijas, iškyla žaliųju erdvių miestuose fizinių charakteristikų (ploto, formos - planinès konfigūracijos, turinių ir kt. savybių) fiksavimo būtinybė. Palyginamajai analizei parinkti žymiausi miestų parkai pasaulyje, panašaus (į Šiaulių miesto centrinį parką) mastelio miestų parkai Europoje ir 6 didžiųjų Lietuvos miestų centriniai parkai urbanizuotoje aplinkoje, t. y. centrinèje miesto dalyje. Jie lyginami savo:

- fiziniu dydžiu - plotu,

- fiziniais ir kompoziciniais elementais (želdynais, pieva, vandens telkiniais, skulptūromis, amfiteatrais, mažosios architektūros objektais),

- pramogų gausa (pasivaikščiojimo galimybèmis, vaikų žaidimo aikštelèmis, žvejybos, čiuožinèjimo ant ledo galimybèmis, atrakcionais, restoranais, kavinèm, muziejais, meno galerijomis ir pan.),

- propaguojamomis neprofesionaliomis sporto šakomis (beisbolo, teniso, tinklinio žaidimo galimybèmis, taip pat atsižvelgiama ị tai, ar yra kur bėgioti, važinèti dviračiais, riedučiais, žaisti krepšini, futbolą ir pan.).

Nagrinëjant žymiausius pasaulio miestų centrinius parkus, aišku tampa tai, kad kuo didesnis jų plotas, tuo sudètingesnè erdvinè struktūra. Todèl kartais atrodo, kad juose teikiamų paslaugų ir galimų funkcinio naudojimo būdų kiekis tiesiogiai priklauso nuo fizinio dydžio, t. y. teritorijos ploto. Tačiau ši pirminé prielaida yra tik iš dalies teisinga. Mažesni fiziniu dydžiu parkai paprastai yra tik morfologiškai aiškesni, nes savo planine forma atitinka vieno ar kelių kvartalų dydžius, o paslaugų spektras varijuoja nuo keleto iki keliolikos funkcijų. Morfologine prasme parkus galima skirstyti ị keletą tipologinių grupių, kurios skiriasi išorinès formos ir vidinès organizacijos santykiu. Užstatymo laipsnio įvertinimas miesto parke (arba santykis su užstatymu) glaudžiai siejamas su pačia morfologine forma. Pati pradinė yra parkas-kvartalas, visos kitos yra jos modifikacijos:

- „apkarpytas“ kvartalas;

- reikšmingai užstatytas kvartalas parko teritorijoje;

- reikšmingai užstatytas kvartalas parko prieigose;

- mišrus.

Vadovaujantis tradicine samprata, kuri egzistuoja tik istoriškai seniausioje miesto dalyje, „švariausia“ parko forma šiuo atveju laikoma neužstatyta ir su aiškiomis struktūrinèmis ribomis teritorija - parkaskvartalas. Ši viešoji erdvè, apribota struktūrinèmis ribomis - gatvėmis, želdynais ir pan., iš esmès atitinka aikštès sampratą (aikštė miesto centrinèje dalyje neužstatytas kvartalas). Tačiau miestų centrinių dalių parkai dažniausiai būna įvairių tarpinių modifikacijų, nes šiose dalyse parkai buvo kuriami kaip neatskiriamos urbanizuotų teritorijų sudètinès dalys, turinčios tam tikrų nereguliarumo bruožų (šalia pilių, dvarų ir pan.). Tuo metu ịvairiomis erdvinemis ir kompozicinèmis priemonemis buvo stengiamasi dirbtinai sukurti gamtos kampeli urbanizuotoje aplinkoje. Tiesa, kai kurie parkai būdavo tiesioginiai gamtinių teritorijų tęsiniai miestuose ar ilgainiui, plečiantis miestui, būdavo integruojami ị miesto struktūrą, t. y. iš dalies urbanizuojami. Todèl lyginti reiktų ne parko dydị ir jame teikiamų paslaugų kiekị, o parko techninị îrengimo laipsnị ir su tuo susijusị jo teritorijos funkcinị issisavinimą.

Iš 2 pav. vaizduojamų pasaulio ir Lietuvos parkų (išrikiuotų pagal savo fizinį dydị) galima matyti, kaip drastiškai kintant parkų plotui (šimtus kartų) kai kurios jų funkcinès charakteristikos kinta nežymiai (2-3 kartus) (Alistratovaitè-Kurtinaitienè ir kt. 2009). Taip yra todèl, kad šios paslaugu grupès (neprofesionalios sporto šakos ir kitos pagrindinès funkcijos bei pramogos) yra universalios ir jų egzistavimas parke yra minimalaus jo kaip viešosios erdvès gyvavimo rodiklis. T. y. ta pati rekreacine veikla esant tam tikram minimaliam įrengimo lygiui įmanoma propaguoti tiek Niujorko Centriniame parke, tiek Šiauliuose ar kitame miesto parke.

Beveik visi išskirti fiziniai ir kompoziciniai elementai egzistuoja miesto parkuose. Tai savotiški poilsio atributai, miesto parko vizitinè kortelè.

Kiek didesnio įrengimo laipsnio reikia įvairioms komercinėms veikloms (kavinių, parodų, koncertų ir pan.) vystyti, tačiau jos gali būti vykdomos mobiliuose statiniuose, kurie užtikrina lankstesnị parko teritorijos panaudojimą. Reikšminga tokiu atveju gali tapti visuomeninès organizacijos ir parko gretimybè, nes dalị savo veiklos ji gali perkelti ị viešąją erdvę ir taip užtikrinti jos priežiūrą (tokią galimybę turi ir Šiaulių miesto parkas).

Aptariant Lietuvos miestuose, jų centrinèse dalyse esančius parkus matoma parko ribų mažinimo tendencija: savo evoliucijos pradžioje (paties parko užgimimo ar jo kūrimo) dažniausiai buvo parkas-kvartalas, tačiau dèl ịvairių ekonominių sąlygų (sovietinių metų), įstatymų painiavos (po 1990-ųjų m. žemès grąžinimo) dauguma Lietuvos parkų centrinèse dalyse yra sumažintos morfologinès formos. Šiaulių miesto parko atveju analogiška - struktūrinès parko ribos nyksta skverbiantis privačiai nuosavybei, fizinès ribos niveliuojamos - jos nebesutampa su gatvėmis. 

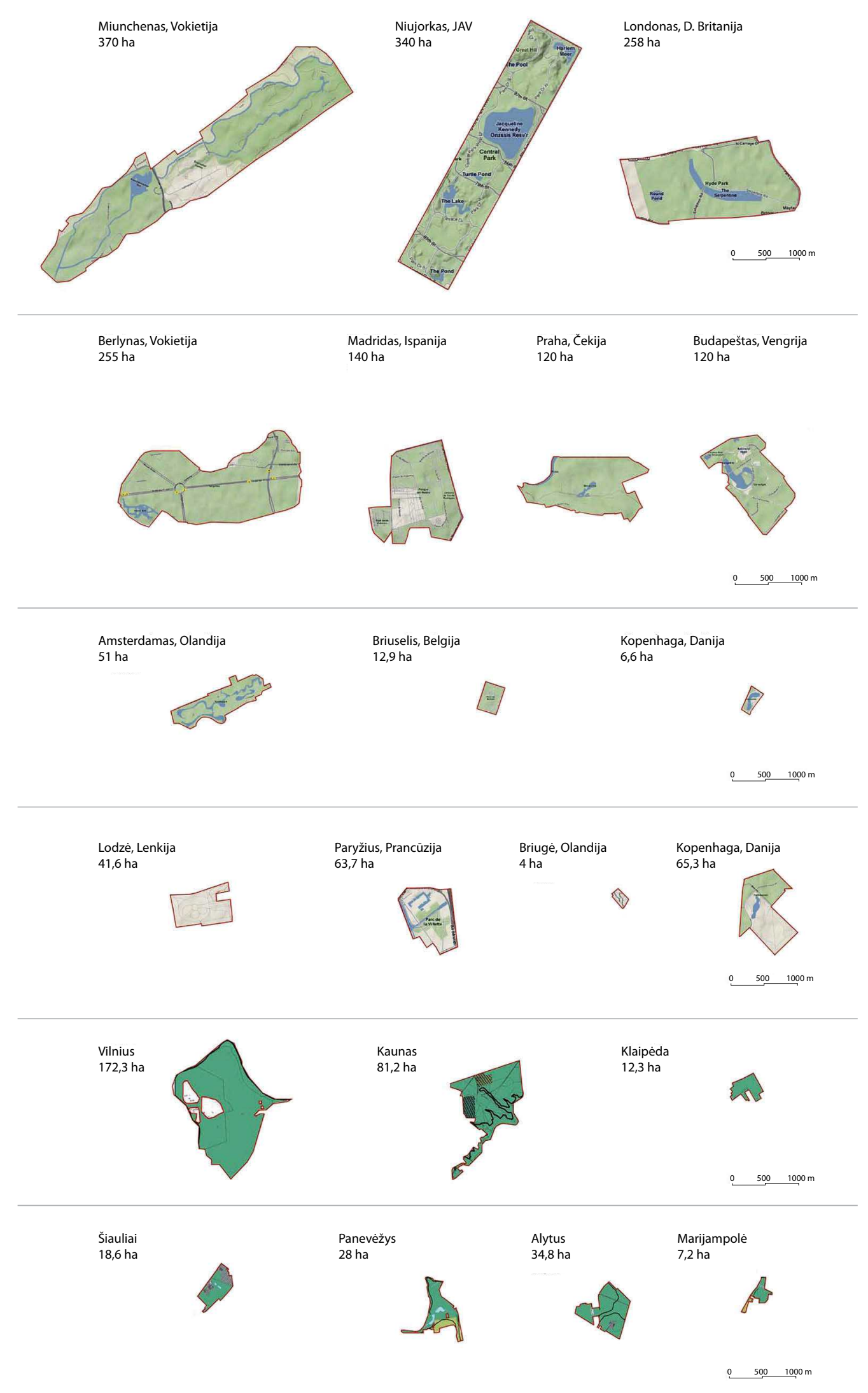

2 pav., a. Miestų parkų urbanizuotoje aplinkoje lyginamoji schema (Alistratovaitė-Kurtinaitienè ir kt. 2009)

Fig. 2, a. Comparative scheme of city parks in urban environment (Alistratovaitè-Kurtinaitienè et al. 2009) 

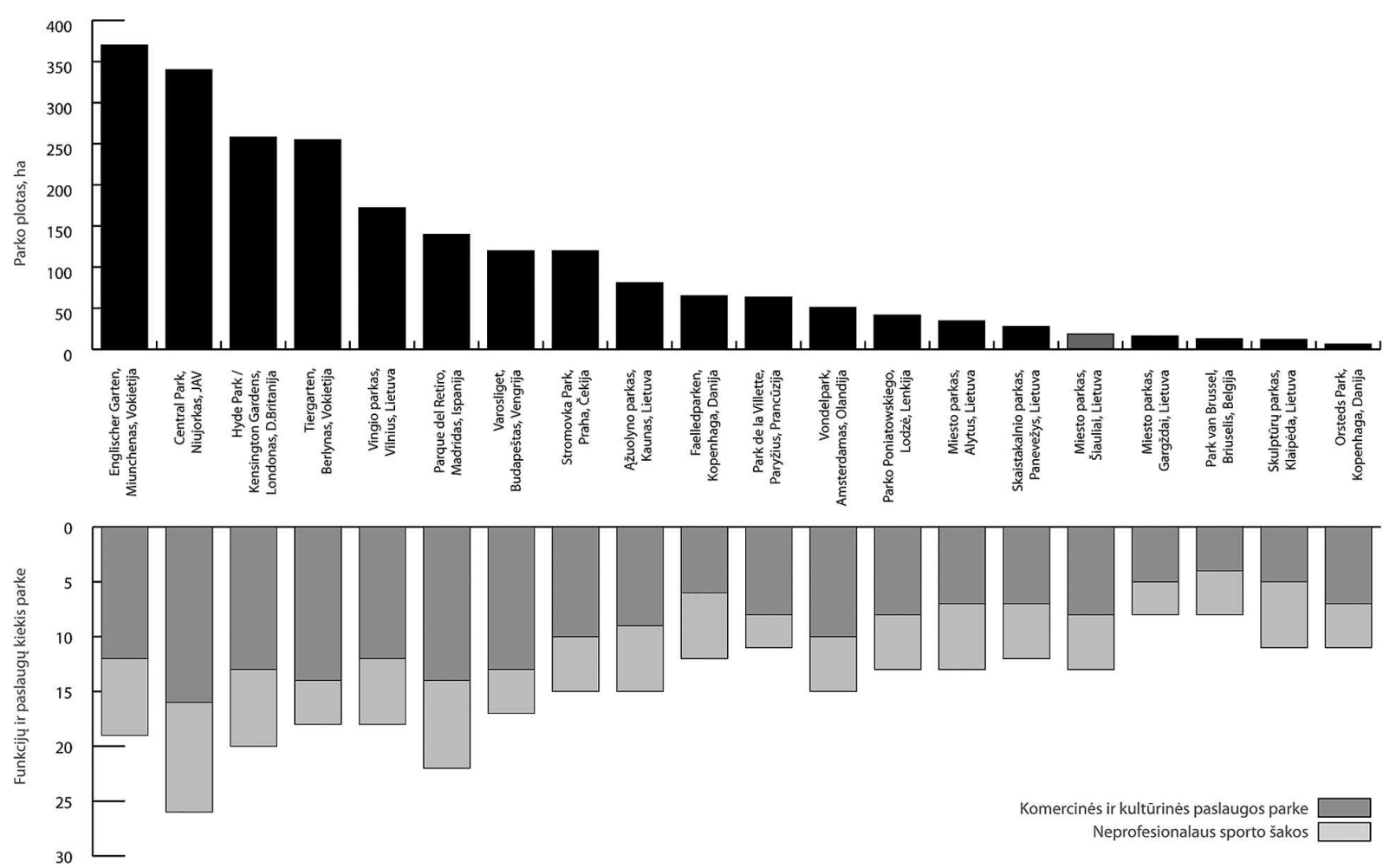

2 pav., b. Miestų parkų urbanizuotoje aplinkoje palyginimo grafikas (Alistratovaitè-Kurtinaitienè ir kt. 2009)

Fig. 2, b. Comparative diagram of city parks in urban environment (Alistratovaitè-Kurtinaitienè et al. 2009)

\section{Šiaulių miesto parko teritorijos analizè}

Šiaulių miesto atveju kartojasi tie patys reiškiniai: iki tol vyravusị dèmesį urbanizaciniams procesams šiandien keičia naujas požiūris ị rekreacines miesto erdves. Rengiant Šiaulių miesto bendrąji planą ${ }^{3}$ ieškoma naujų ryšių tarp gamtinių miesto vertybių ir urbanizuotų teritorijų. Šio proceso fone vietos valdžia (ir bendras socialinis klimatas) vèl ima pripažinti kultūrinę parko vertę. Didelę reikšmę tam turi parko prieigos, formuojančios psichologini parko klimatą. Todèl parko atgaivinimas - atkūrimas - glaudžiai siejamas su kaimyninemis teritorijomis (jų funkcijomis, hierarchija miesto struktūroje ir pan.).

Darbo pradžioje suformuluoti rezultatai:

- identifikuoti parko erdvès rangą bendrojoje miesto struktūroje (ypač miesto gamtiniame karkase ir žaliųjų plotų sistemoje);

- identifikuoti bei ịvardinti parko teritorijos svarbą Šiaulių miesto urbanistinejje struktūroje ir jos elementų vertybinëje hierarchijoje;

\footnotetext{
3 Jị prieš dešimtmetị pradèjo rengti dabar jau „numarinta“ Savivaldybès įmonè „Siaulių planas“ ir vèliau jis buvo patikètas rengti vilniečių bendrovei „Urbanistika“.
}

- įvertinti ankstesnių Šiaulių miesto parko ir jo prieigų tvarkymo planų sprendinius bei įvykusias transformacijas;

- atlikti Šiaulių miesto parko teritorijos esamos padèties analizę;

- parengti Šiaulių miesto parko teritorijos siūlymus.

\section{Šiauliu miesto parkas miesto} gamtiniame karkase ir žaliụjų plotų sistemoje

Pagal Lietuvos Respublikos teritorijos Bendrojo plano teritorijos erdvine koncepcija teritorinio vystymo atsvara jos funkciniam stuburui yra tarptautinès bei nacionalinès svarbos gamtinio karkaso ašys (Šiaulių... 2008). Svarbiausia gamtinio karkaso paskirtis urbanizuotos aplinkos sąlygomis - reguliuoti kraštovaizdžio urbanizacijos ir technogenizacijos plètrą, saugoti gamtos rekreacinius išteklius. Šị teiginị labiau iliustruoja principiné Šiaurès Lietuvos gamtinio karkaso struktūra (3 pav.) ir gamtinio karkaso rajoninis lokalizavimas Šiaulių miesto apylinkèse (4 pav.).

Šiaulių miesto administracinèse ribose ir prieigose išskiriamos regioninès bei rajoninès svarbos geoekologinès takoskyros. Šiauliai - tai miestas stambiu geosistemų sandūroje. Regioninès svarbos takoskyra 
apima pietinèje miesto dalyje esantị Rèkyvos ežerą, o Šiaulių pietinè dalis patenka ị Lietuvos nacionalinès svarbos gamtinio karkaso teritoriją.

Kraštovaizdžio specialistų nustatyta, kad urbanizuotame kraštovaizdyje esantys miesto žaliosios aplinkos elementai turi jungtis tarpusavyje ir taip sudaryti gamtinio karkaso sistemą. Šiauliuose miesto teritorija dalinama i 3 morfologinius segmentus: intensyviai urbanizuota miesto dalis (aktyvioji teritorija), gamtine kompozicinè ašis, jungianti vandens telkinius (santykinai aktyvios teritorijos), ir Zoknių oro uosto teritorija (pasyvi teritorija) (5 pav. $)^{4} .5$ pav. gamtinio karkaso samprata miesto urbanistineje struktūroje skiriasi nuo tradicinès kraštovaizdžio specialistų sampratos. Gamtinis karkasas miesto urbanistinèje struktūroje suprantamas kaip struktūrinis elementas, turintis ati- tinkamą urbanistinị režimą, t. y. urbanizacijos laipsni - tai gamtinių ir antropogeninių elementų derinys, prioritetą skiriant gamtiniams elementams.

Minètose gamtinèse zonose (kurias apima regioninė geoekologinè takoskyra ir miesto žalioji ašis) rekomenduojamas minimalus urbanizacijos laipsnis (ypač vengiant didelių objektų). Tai atitinka teritorijų technogeninị aktyvumą. Centrinis miesto parkas nepatenka nè í vieną gamtinị ruožą, priešingai yra intensyviai urbanizuotoje teritorijoje. Schemose tiek Šiaurès Lietuvos mastu, tiek ir miesto mastu išskiriamas gamtinis karkasas neprasilenkia vienas su kitu.

Parku sklaida mieste. Šiaulių miesto bendrojo plano sprendiniuose planuojama žaliųjų plotų sistema užima 1634,2 ha - 18,5 \% miesto teritorijos. Didžioji dalis parkų išsidèstę santykinai aktyvioje teritorijoje pagal

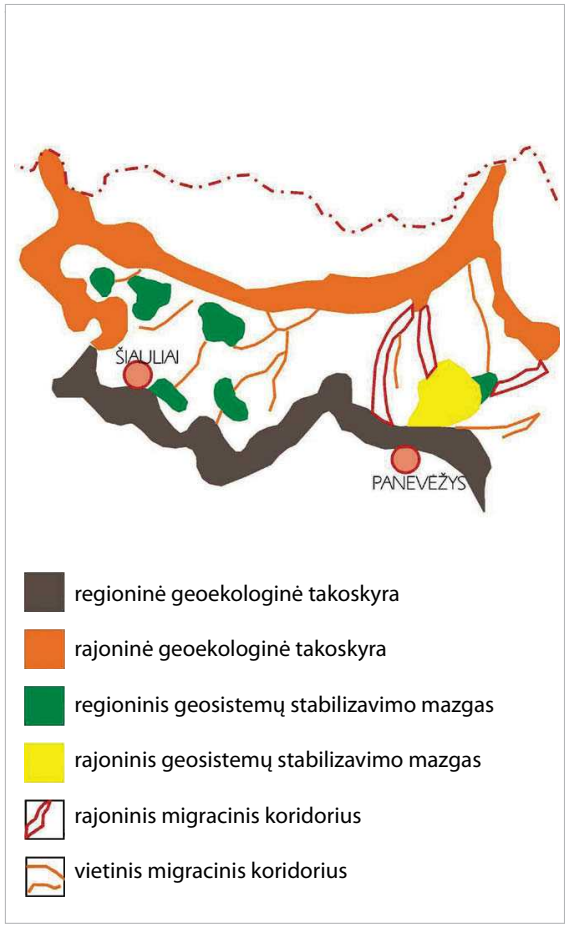

3 pav. Principinė Šiaurès Lietuvos gamtinio karkaso struktūra (pagal P. Kavaliauską 1992)

Fig. 3. Principled structure of green frame in the North Lithuania (by P. Kavaliauskas 1992)

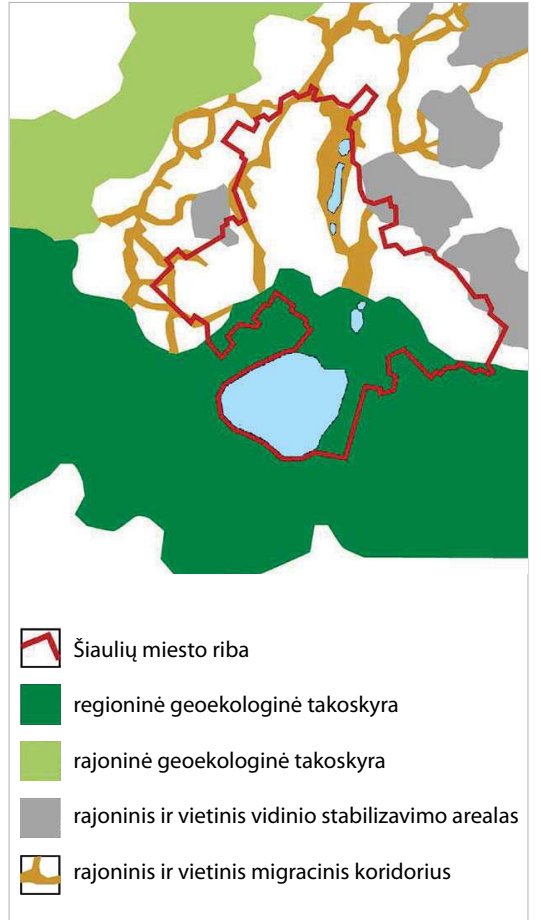

4 pav. Gamtinio karkaso rajoninis lokalizavimas Šiaulių miesto apylinkèse

Fig. 4. Regional localization of green frame in surroundings of Šiauliai city

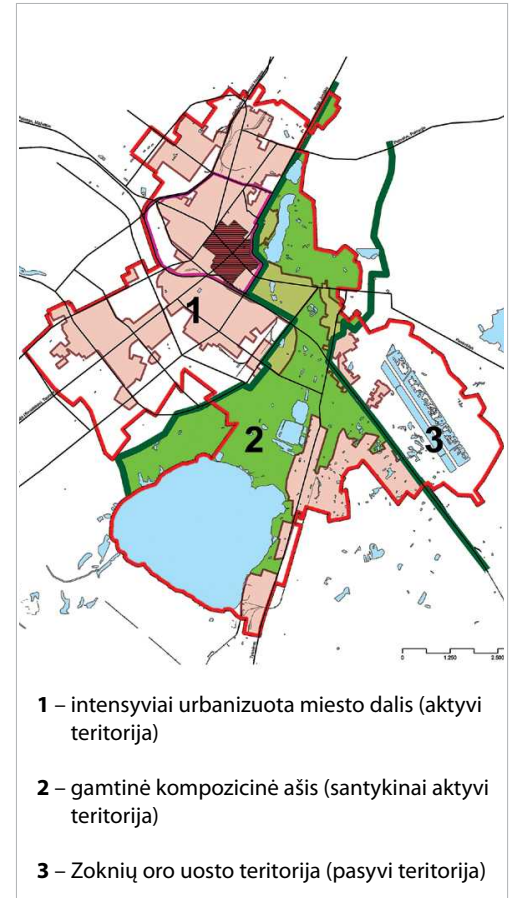

5 pav. Gamtinis karkasas miesto urbanistineje struktūroje

Fig. 5. Green frame in urban structure of city

\footnotetext{
4 Dar 2002 m. vykusiuose ikiprojektiniuose darbuose (tyrimo etapu rezultatai) buvo išskirta gamtinė kompozicinė ašis, sujungianti ne tik vandens telkinius, bet ir miško parkus. Tokiai gamtinio karkaso kompozicinei ašiai iš esmès pritare BP ikiprojektinių tyrimu ekspertai (tai Geologijos ir geografijos institutas, darbo vadovas doc. dr. R. Baubinas), atlikinèję BP dalị kūrę ekologinę aplinką.
} 
technogeninị laipsnị, t. y. miesto gamtineje kompozicinejje ašyje (Talšos, Salduvès, Hidro, Prūdelio, Pabalių, Rèkyvos, Zoknių, Margių miško, Zoknių miško parkai), o aktyvioje teritorijoje toks pats parkų skaičius užima kur kas kuklesni plotą (Gubernijos, Centrinis, Senasis Didždvario, Naujasis, Dainų, Lieporių parkai) (6 pav.). Salduvès, Talkšos, Dainų parkams siūlomas valstybinio miško statusas. Miško plotai prie Rèkyvos ežero ir toliau laikomi valstybiniais miškais. Valstybinio miško salelès numatomos ir kitose miesto vietose - Pabaliuose, Zokniuose. Neaiškumų kelia klausimas, kaip mieste bus administruojami ir tvarkomi valstybiniai miškai.

Atkuriant privačią nuosavybę pretenduojama i Talkšos, Salduvès miško parkus. Dèl šios žemès vyksta teismai ir jie dar nesibaigia. Prieš dvejus metus miesto Taryba apsisprendè didžiąją dalị Talkšos ir Salduvès parkų išlaikyti visuomenès poreikiams bei patvirtino jų detaliuosius planus. Pretendentų i šią žemę yra tiek, kad ją grąžinus parkų praktiškai nebeliktų. Senasis Didždvario ir centrinis parkai lieka miesto parkais.
Reikia pažymèti, kad Šiauliai kaip nė vienas kitas miestas turi daug skirtingų parkų, tačiau šių žaliųjų miesto erdvių integravimas ị kasdienị miestiečių gyvenimą (optimizuojant lankytojų srautus ir didinant pasiekiamumą bei paslaugų skaičių, keliant naudojimosi kultūrą ir pan.) yra vangus.

Statistiniai duomenys. Urbanizacijos plètra vertinama pagal natūralių (gamtinių) teritorijų ir urbanizuotų teritorijų santyki, todèl pagal LR žemès fondo duomenis (1997-01-01) šis santykis Šiaulių mieste buvo 0,78, o 2005-01-01 duomenimis šis santykis sumažèjo iki 0,6.

Pagal Geologijos ir geografijos instituto specialistų tyrimus, statistiškai vertinant, želdynų kiekis Šiaulių miesto teritorijoje yra pakankamas. Tačiau toks žaliosios aplinkos normavimas dažnai suprantamas tik kaip želdinių kiekis, tenkantis vienam gyventojui, arba jų santykis su visa miesto teritorija. Tačiau yra svarbus ne tik bendras želdinių kiekis, bet ir jų išsidèstymas (rajone). Todèl šiuo statistiniu rodikliu nę̇manoma nustatyti kraštovaizdžio kokybès, bet jis svarbus urbanizacinių procesų kontrolei.

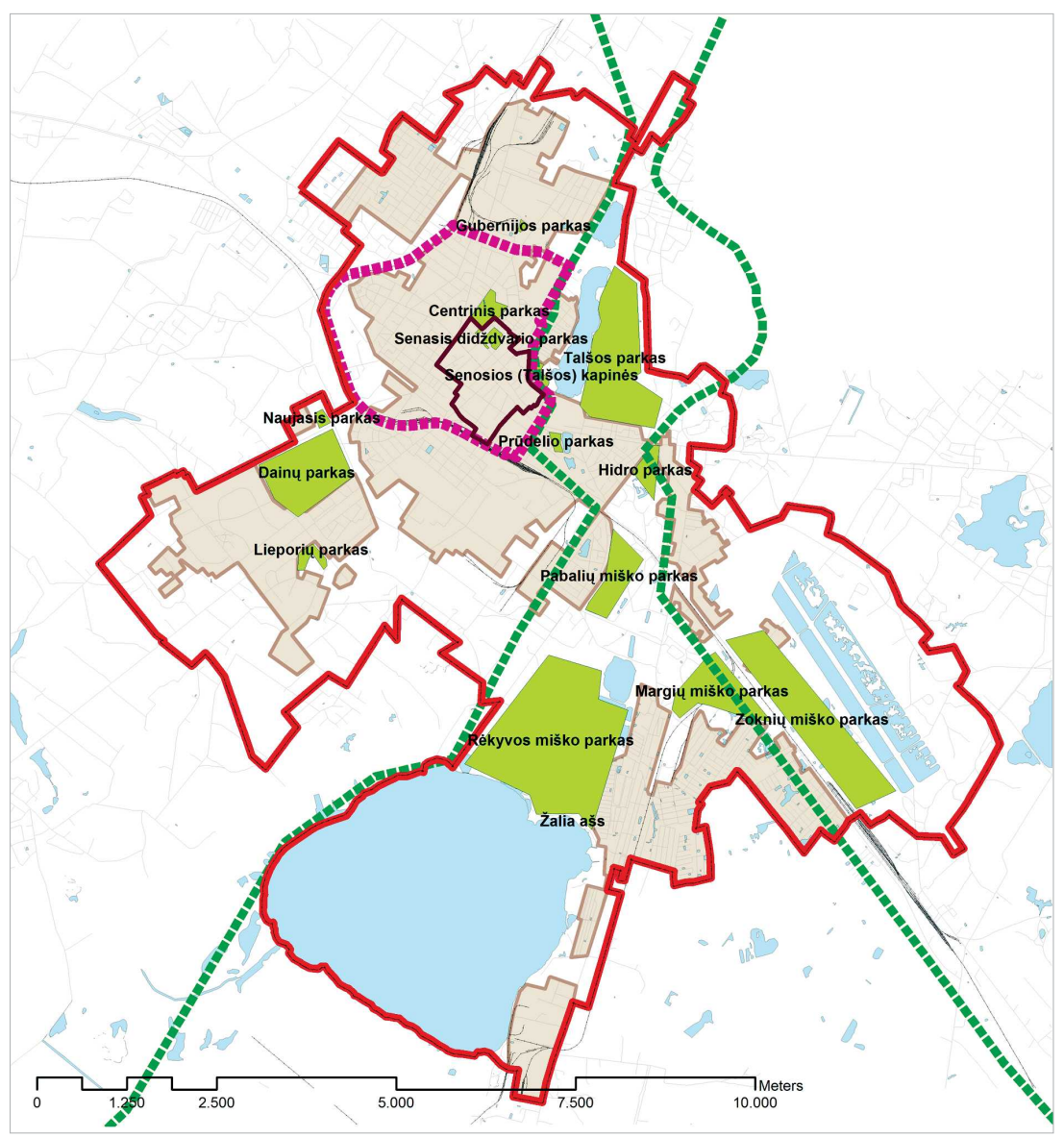

6 pav. Žaliųju plotų sklaida Šiaulių mieste

Fig. 6. Distribution of green areas in Šiauliai city 
Istatymai. Svarbus klausimas yra tinkamas miestų žaliosios aplinkos elementų klasifikavimas, nes pagal tam tikrą klasifikaciją žaliosios aplinkos kategorijos turètų skirtis ir tvarkymo bei administravimo programomis. Šiuo metu urbanistinis teritorijų planavimas yra glaudžiai susijęs su juridinio kai kurių teritorijų ir žemès sklypų statuso apibrèžimu - t. y. su tikslinès žemès naudojimo paskirties nustatymu. Dabartinè galiojanti miesto želdynų klasifikacija yra pateikta Miestų ir miestelių teritorijų bendrųjų planų rengimo taisyklèse. Dažnai patys kraštovaizdžio specialistai tarpusavyje tikslina sąvokas, aiškina jas atskirai, tad labai trūksta oficialių terminų, kurių nebuvimas yra reali problema ir kartu painiava vartojant terminus ,želdynai“, „žalioji aplinka" ir pan. Vadovaujantis Miestų ir miestelių teritorijų bendrųjų planų rengimo taisyklemis (2004) bei nustatytu žemès naudojimo būdo pagal tikslinę paskirtị suskirstymu (2005) išskiriami:

- miškai - miško parkai ir miesto miškai (miškų ūkio paskirties žemèse);

- urbanizuotų teritorijų viešosios erdvès - aikštès, parkai, skverai (kitos paskirties žemès bendro naudojimo teritorijose);

- kiti saugotini želdynai (laisvo valstybinio žemès fondo žemèse pavieniui ar bendrijose augantys savaiminès kilmès ar žmonių pasodinti medžiai bei krūmai).

Tad vadovaujantis šiais įstatymais konstatuojama, kad Šiauliu miesto centrinis parkas yra urbanizuoty teritoriju viešoji erdvè.

\section{Urbanistinė Šiaulių struktūra ir vertybinė jos elementų hierarchija}

Iki Antrojo pasaulinio karo Lietuvos miestuose galima fiksuoti daugiau ar mažiau nuoseklią urbanistinès struktūros raidą. Sovietiniais metais ši plètra iggavo prievartinị mastą, iškreipe nuosekliai susiklosčiusius užstatymo principus, privačios nuosavybès nebuvimas lèmé dideles užstatymo struktūros anomalijas miestų centrinèse dalyse. Tai ypač akivaizdu lyginant tarpukario pabaigos ir sovietinių metų pabaigos istorinius miestų planus, centrinių dalių užstatymo rodiklius (tarp kurių nepagrịstai dideli šuoliai nagrinejjant net tuos pačius centrinès dalies kvartalus) (Alistratovaitė 2004).

Lyginant Šiaulius su tapataus dydžio miestu vakaruose, Šiauliai turi nemenkas plètros galimybes. Šiuo metu juose vykstantys objektyvūs ir neišvengiami užstatymo intensyvinimo procesai užprogramuoja urbanistinès koncepcijos būtinybę, be kurios plètra dažnai virsta stichine.
Šiaulių miesto centrinè dalis po $2009 \mathrm{~m}$. patvirtinto bendrojo plano (patvirtintas 2009-01-29 Šiaulių miesto tarybos sprendimu Nr. T-1) igavo aiškias struktūrines ribas (toliau tęsiamas centro detalusis planas). Visuose trijuose sovietiniais metais rengtuose bendruosiuose planuose (nors jie parengti kitomis ekonomikos sąlygomis, tačiau nepaisant to jie lengvai skaitomi, aiškiai suvokiama pagrindinè idejja) aiškiai apibrèžtas Šiaulių miesto centrinis rajonas, kurio ketvirtadalị galima laikyti senamiesčio dalimi. Tačiau dèl neidentifikuotos saugomų teritorijų sampratos šiai teritorijai nesuteikiamas senamiesčio statusas. Pagal patvirtintą BP miesto centrinè dalis plètojama kaip intensyvaus užstatymo zona, turinti tam tikrus užstatymo kompozicinius principus.

Šiuo metu išskirtąją centrinę dali galima dalinti i dvi dalis (ties Žemaitès gatve), kurios yra labai nevienodos teritorijų ísisavinimo laipsniu (t. y. užstatymo ekvivalentu) - labai dideli užstatymo skirtumai: vienoje dalyje (ị kurią ieina senamiesčio dalis) urbanizacinis laipsnis aukštas (dominuoja perimetrinis užstatymas), kitoje - žemas (dominuoja sodybinio užstatymo morfotipas). Joje neišvystyta socialinè ir paslaugų infrastruktūra, dèl šios priežasties ši dalis artimesnè priemiestinei miesto zonai negu miesto centrui.

Iš 7 pav. vaizduojamos centrinès dalies fragmento galima stebèti intensyvų kvartalų užstatymo charakterị su unikalia viešųjų erdvių sistema: Vilniaus gatvė (sovietiniais metais paversta pèsčiujų bulvaru) - reprezentacinè miesto viešoji erdvė, kurioje koncentruojasi komercinès paskirties objektai, kvartalo atstumu suveria tarpusavyje atskiras viešąsias erdves ị vieną sistemą (Saulès laikrodžio aikštę prie šv. Jono kalnelio ir Senųjų Talšos kapinių, Prisikèlimo aikšstę, Didždvario parką ir Centrinį miesto parką). Tokia viešųjų erdvių ịvairovė unikali kompaktišku išsidėstymu miesto centrinejje dalyje, kurianti erdvių tekẻjimo (pulsavimo) įspūdị ne tik plane, bet ir natūroje. Miesto centrinès dalies struktūroje atlieka tarpininko vaidmenį tarp skirtingo užstatymo morfotipų (perimetrinio ir sodybinio). Šios viešujų erdvių sistemos respektavimas ir tolesniame miesto centrinès dalies detaliajame plane su joms nustatytu urbanizavimo laipsniu išspręstų daugelị klausimų, susijusių su naujų sklypų formavimu žaliosiose zonose.

Viešųjų erdvių kuriamas charakteris yra išsaugomas ir tobulinamas formuluojant tolesnes miesto centrinès dalies užstatymo plètros gaires (jos tapo pagrindu detaliajam centro planui), kuriose anksčiau dominavusị Vilniaus ir Tilžès gatvių kryžių bei istorinio centro branduoli - Prisikèlimo aikštę ir katedrą - 
papildo alternatyvus naujas specializuotas centras naujas mazgas (8 pav.) (Alistratovaitè et al. 2007b). Jis kuriamas pagrindinių intensyvaus (tiek pèsčiųjų, tiek transporto) naudojimo gatvių (Žemaitès - C1 ir Vilniaus C1/C3) susikirtime. Kuriamas mazgas sutampa su centrinès dalies geometriniu centru, taigi išsaugomas balansas tarp struktūrų tipų. Sovietiniais metais intensyvaus užstatymo fragmentai sodybinio užstatymo zonoje plètojami kaip intensyvaus užstatymo branduoliai sujungiant potencialias plètrai teritorijas $\mathfrak{i}$ urbanizacinius ruožus. Taip žemo urbanizacinio laipsnio centrinès dalies fragmentas igauna miesto centrui būdingą ịvaizdị, suaktyvejja naudojimasis viešosiomis erdvemis, o tai priverčia miesto savivaldą sparčiau jas pritaikyti prie kintančių funkcinių (kartu ir ekologinių) poreikių.

Centrinis miesto parkas yra prie intensyvaus naudojimo gatvès, naujai kuriamo centro prieigose, ir ribojasi su senamiesčio dalimi (tiesioginis ryšys su miesto kultūros namais, P. Višinskio biblioteka). Ši parko dislokacija garantuoja aktyvų miestiečių lankymąsi jame, tačiau dèl formuojamo parko psichologinio klimato (nebaigtos statybos), mažinant parko eksploatavimo išlaidas, jis nèra patrauklus, dar blogiau, apleistas. Todèl parko atgaivinimas - atkūrimas - glaudžiai siejamas su kaimyninèmis teritorijomis ir jų naudojimu.

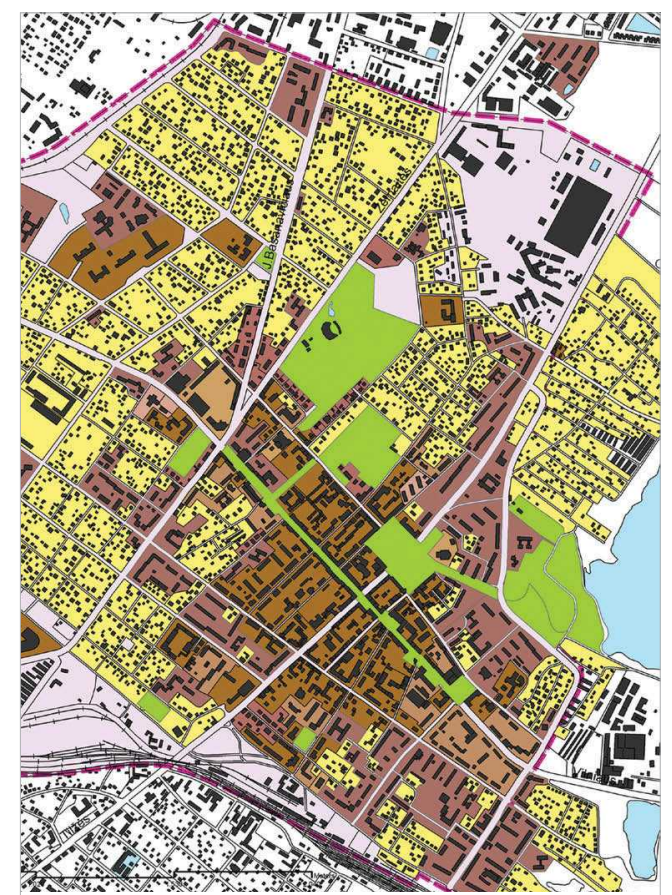

EKSPLIKACIJA

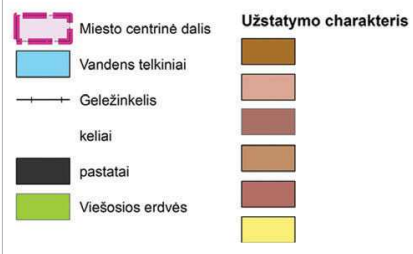

7 pav. Šiaulių miesto viešujų erdvių sistema bei užstatymo charakteris

Fig. 7. System of public spaces and character of buildup in Šiauliai
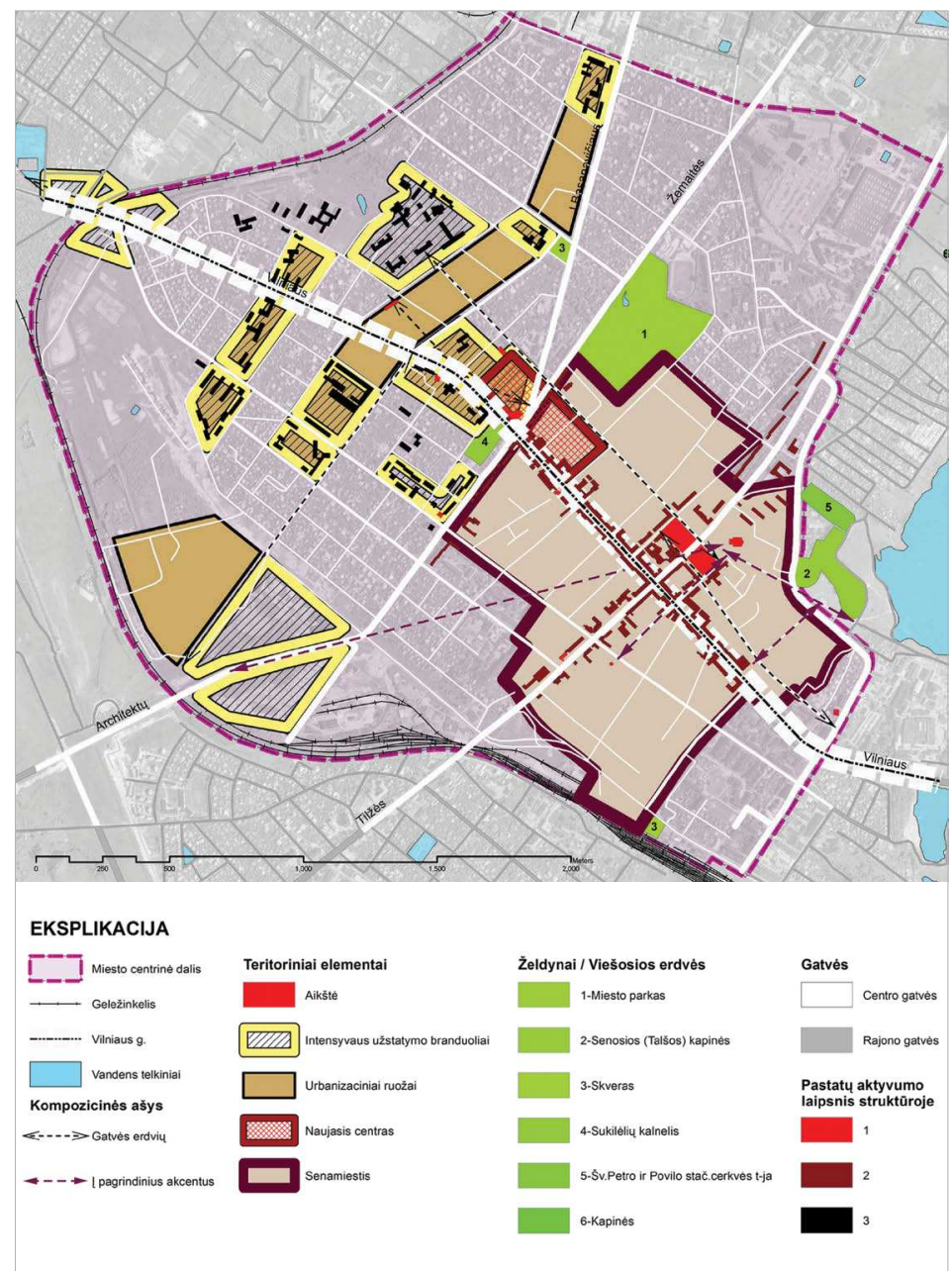

8 pav. Miesto centrinès dalies užstatymo plètros gairès (Alistratovaitè et al. 2007b)

Fig. 8. Development of buildup in central part of city (Alistratovaite et al. 2007b) 


\section{Šiaulių miesto parko teritorijos transformacijos}

Šiaulių centrinio parko struktūrinių ir juridinių ribų kitimo raidos glaudžiai susijusios. Dabartinis centrinis miesto parkas neatsitiktinai įkurtas prie Didždvario parko, kuri pradejo kurti Antanas Tyzenhauzas, o iš esmès pabaigè Vladimiras Zubovas. Siekiant nustatyti parko vertybes, tikslinga panagrinèti parko funkcinę ir erdvinę raidą. Pagrindiniais parko etapais laikomi šie gyvavimo ir transformacijų tarpsniai (9 pav.):

- prieškaris: iki tol šioje vietoje buvusi sena gyvenvietè ilgainiui virto dideliu priemiestiniu vienkiemiu, priklausiusiu Šapirų šeimai. Manoma, kad Beras Šapira buvo pirkęs iš Zubovo dvaro didelį žemés plotą, pasistatęs trobesius, vertèsi daržovemis. Šapiru vienkiemis turèjo ir savo pavadinima "Kanapiškiai“", bet laikui bègant šis pavadinimas buvo pamirštas. Dali šsio vienkiemio teritorijos sudarè šlapia, durpèta žemè ir miesto gyventoju tarpe paplito pavadinimas
„Šapiru pievos" išlikęs iki mūsų dienų. Kaizerinès Lietuvos okupacijos metais Šapiru vienkiemis buvo prijungtas prie miesto ${ }^{5}$. Taigi teritorija naudojama ūkinèms reikmèms;

- sovietiniai metai: pirmiausia pokario metais, šalia miesto valymo ir atstatymo darbų, miesto visuomenè Šapirų pievose èmèsi kurti ir naująji miesto parką. Jau 1947 m. spalio mèn. čia iškasta 3850 duobiu medeliams, nuvalyta 6220 išilginiu metru alejų. Taigi teritorijai suteikiami pagrindiniai viešosios erdvès bruožai. Parkas toliau augo ir po truputi virto aktyvia miestiečių viešąja erdve, turinčia integruotą sporto funkciją - prie gatvès numatyta vieta sporto salei, o už jos - stadionui, o tai faktiškai ir buvo parko šiaurinès dalies urbanizavimo pradžia. Taip pat sovietiniais metais parke įrengta vaikų žaidimo aikštelè - atrakcionai, vasaros koncertų estrada. Parke prisodinta daug medelių, daugiausia talkų metu. Atlikus parko
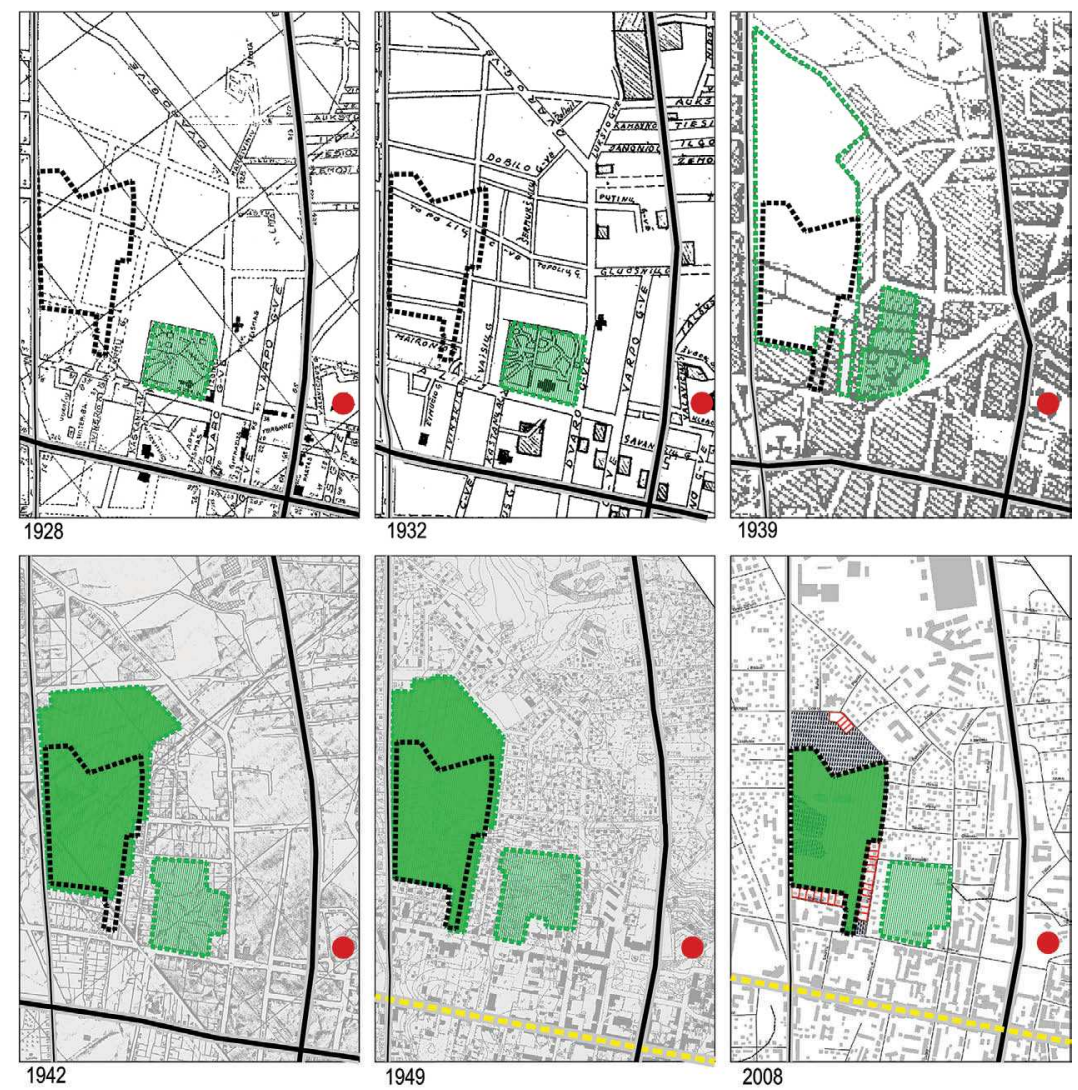

9 pav. Miesto centrinio parko evoliucija

Fig. 9. Evolution of central city park

5 Šiaulių miesto centrinis parkas [interaktyvus] [žiūrèta $2010 \mathrm{~m}$. rugsejo 22 d.]. Prieiga per internetą: <http://tic.siauliai.lt/article/view/1238/1/77>. 
želdinių inventorizaciją, nustatyta, kad iš retesnių medžių auga platanalapiai, totoriniai klevai, europiniai maumedžiai, nemažai kitų egzotinių medžių, kurių iki šių dienų išliko nedaug. Didžioji parko dalis apaugusi savaiminiais atsitiktiniais želdiniais, todèl erdvès meninè kokybè yra labai žema. Kiek labiau sutvarkyta pietinè parko dalis, kur daugiausia vyrauja ąžuolai. Kita parko puse - tuopų, beržų bei atsitiktinių mažaverčių medžių mišinys;

- dabartiniai laikai: nepriklausomybès pradžioje pasikeitus žemès nuosavybės santykiams dalis sporto komplekso statinių buvo išparceliuota - valstybe nesugebejjo išlaikyti savo rankose visos sporto infrastruktūros objektų. Panašus reiškinys matomas ir kituose miestuose ne tik Šiauliuose su tais pačiais ar kitais visuomeniniais objektais. Sporto kompleksai, patekę i privačias rankas, virto prekybos centrais, $o$ konkrečiu atveju - Šiauliuose buvo pradètos lošimo namų (kazino) statybos. Tačiau nepasiteisinus investicijai teritorija kartu su pradètomis statybomis bei stadionu perleista kitam savininkui. Kadangi retas investitorius savo teritorijoje plètoja visuomeninès erdvès funkciją, todèl tęsiama sovietiniais metais vykdyta intervencija iz žaliąsias miesto zonas, tik realizuojama jau nebe visuomeninè, bet privati funkcija. Greta sporto komplekso parko rytineje dalyje taip pat formuojami nauji sklypai (vadovaujantis žemės reforma), kuriuose pradèta intensyviai statyti individualius gyvenamuosius namus. To rezultatus galime matyti realiu laiku (10 pav.).

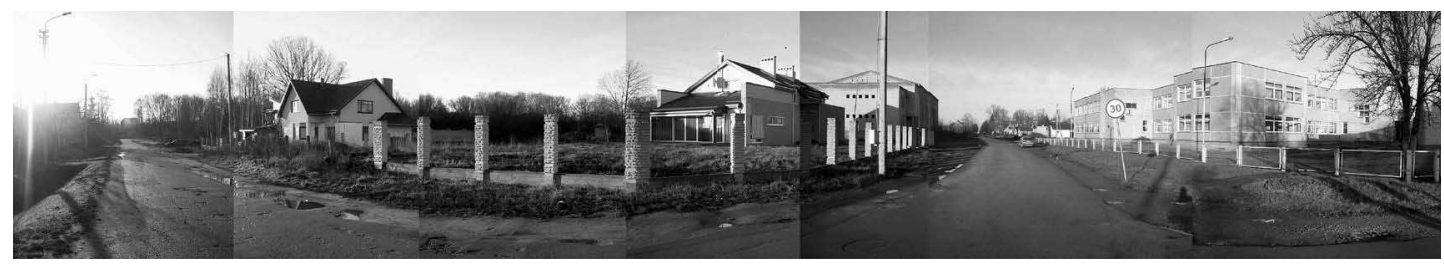

a) po $1991 \mathrm{~m}$. suformuoti nauji sklypai

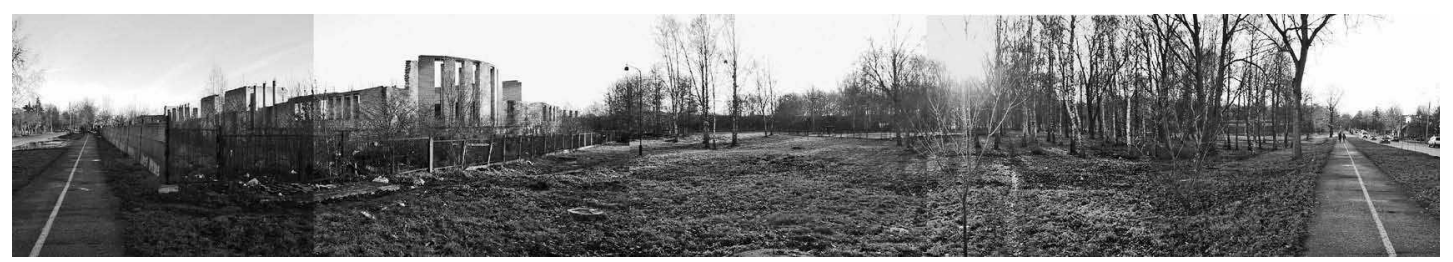

b) lošimo namų griuvėsiai

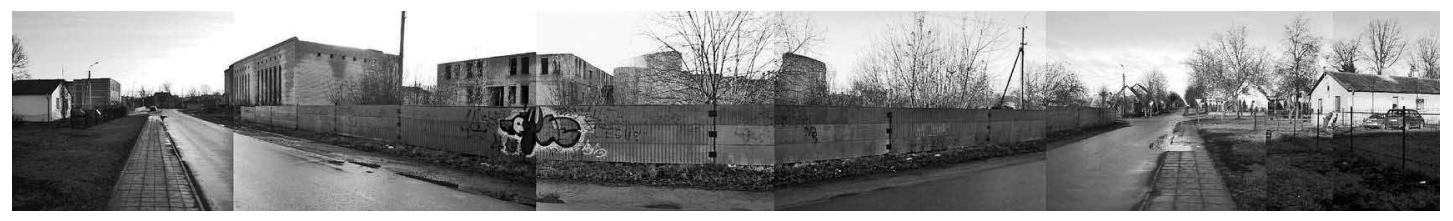

c) lošimo namų griuvėsiai
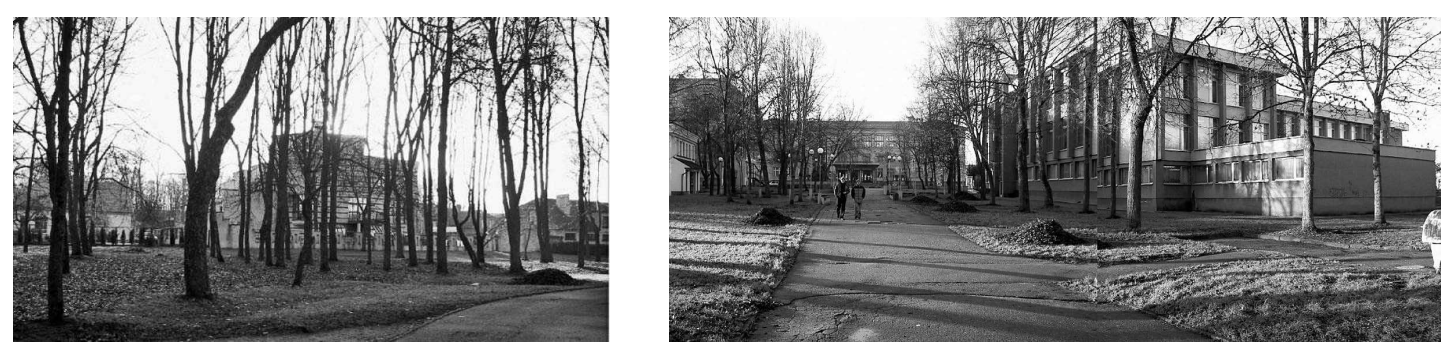

d) užstatymo intensyvumo didejjimas nuo Vilniaus g.

10 pav. Miesto centrinio parko fragmentai

Fig. 10. Fragments of central city park 
Teritorijoje (kuriai priklauso ir miesto parkas) buvęs priemiesčio statusas pateisina užstatymo intensyvumą parko prieigose, jos ypatumas - dominuoja sodybinio užstatymo morfotipas. Tik parko prieigose iš pietinès pusès matomas užstatymo intensyvumo didejimas (11 pav.). 11 pav. pateikiamas gretimų teritorijų užstatymo intensyvumo rodiklis. Toks itin žemas urbanizacinis laipsnis centrinèje dalyje (išskyrus miesto branduoli - senamiesčio dalį) praktiškai prilygsta kaimo vietovei. Kaip pasekmé - neišvystyta socialinè ir paslaugų infrastruktūra. Tad siūlymai intensyviau urbanizuoti miesto centrinę dali yra logiški, o dabar vykstantys užstatymo intensyvinimo procesai objektyvūs ir neišvengiami. Todèl vadovaujantis europietiškomis užstatymo tankumo normomis miesto centrinèje dalyje sklypo formavimą iš dalies galima pateisinti kaip užstatymo intensyvinimo galimybę, tačiau kita vertus belieka konstatuoti viešųjų erdvių ir miestiečiu poreikių ignoravimą.

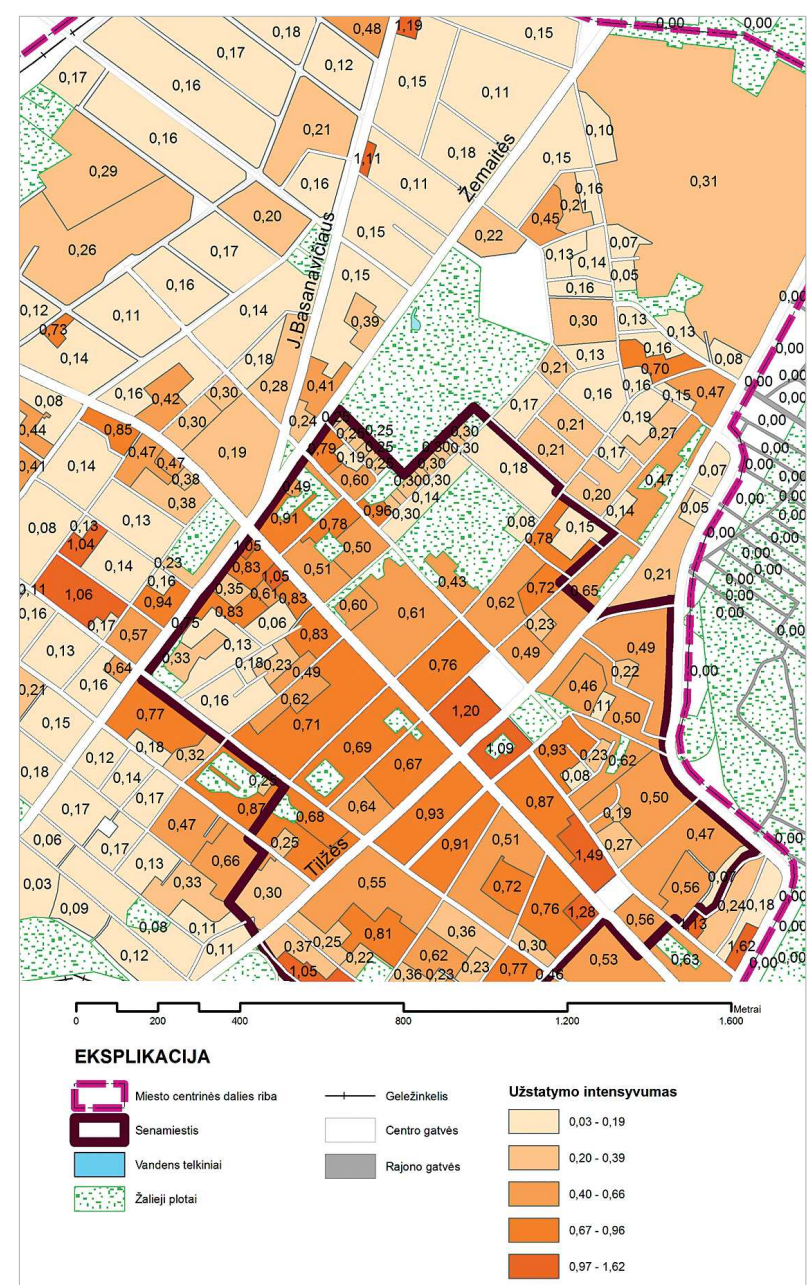

11 pav. Kvartalų užstatymo intensyvumo schema

Fig. 11. Scheme of quarter buildup intensity

\section{Šiaulių miesto parko teritorijos esamos padèties analizè}

Siekiant preliminariai ịvertinti Šiauliu miesto parko vertybes tikslinga panagrinèti parko teritorijos erdvinę ir planinę kompoziciją. Parkas, ribojamas gatvių, yra gana aiškus struktūrinis elementas, turintis aiškias ribas centrinès dalies struktūroje. Tačiau sovietiniais metais šiaurineje parko dalyje prie įrengto stadiono vykdant statybas tarpukariu susiformavusios parko ribos pradejo kisti. Nepriklausomybès pradžioje šioje parko zonoje suformuotas sklypas, kuris nuosavybès teise priklauso privačiam sektoriui ir yra labai didelis $(\sim 3,8 \mathrm{ha})$, viršijantis net tradicinị kvartalo dydị, būdingą Šiauliams (nuo 1,0 iki 3,0 ha'). Tokio didelio sklypo suformavimas miesto centrineje dalyje ir priklausymas vienam savininkui automatiškai sukuria dideles problemas, nes sudaro galimybes atsirasti dideliam objektui, nebūdingam miesto centrui, juo labiau sklypui, kuris yra miesto žaliojoje zonoje, ir kelia dideles diskusijas.

Rengiant miesto centrinio parko galimybių studiją, išryškèjo keletas galimų Šiaulių miesto parko teritorijos zonavimo principų:

1 principas - senos ir naujos struktūrų santykis. Siekiant ši principą taikyti praktikoje, nagrinejamas teritorijos vertybinis potencialas (t. y. nustatomi vertingi teritorijos elementai), identifikuojami naujadarai, ịvertinamas jų teigiamas ir (ar) neigiamas poveikis, numatomas neigiamų padarinių šalinimas arba tam tikras kompensavimo metodas (tarkim, suformuotame sklype taikomi ekologinès urbanistikos metodai, kompensuojamos prarastosios funkcijos ir pan.).

2 principas - teritorijos panaudojimo aktyvumas. Šio principo taikymas konkrečioje situacijoje yra labai glaudžiai susijęs su esamu teritorijos funkciniu panaudojimu, o tiksliau su jos ịrengimu (infrastruktūra).

Remiantis šiais principais vertinamos gretimos teritorijos bei pats parkas su visa takų sistema, esamais (vasaros estrada) ir laikinais (atrakcionai) statiniais identifikuojant esamo urbanistinio karkaso elementus: jungtis - kompozicines ašis (gatvès, pėsčiųjų traktai), svarbius visuomeninius pastatus ( $\mathrm{P}$. Višinskio biblioteka, kultūros namai) (12 pav., a), taip pat išskiriant naujus galimus urbanistinio karkaso elementus su esamo urbanistinio karkaso tąsa (prieigose susiformavusios

6 Pagal A7 lentelę „Urbanistinių morfostruktūros vienetų pasiskirstymas pagal plotą CR" (Alistratovaitè 2004: 84). 
gatvès) (12 pav., b). Remiantis šiais tyrimais sudaromos prielaidos integruoti naujus urbanistinio karkaso ir audinio elementus bei formuoti erdvių hierarchiją (12 pav., c).

\section{Šiaulių miesto parko teritorijos siūlymai}

Pasaulyje yra daug ịvairias viešosios erdvès koncepcijas propaguojančių organizacijų, veikiančių vietiniu ar tarptautiniu lygmeniu. Vienos ju gina modernų, šiuolaikišką viešosios erdvès modelị (šalininkai J. Czerniak, G. Hargreaves, PPS), kitos piestu stoja už istorinių parkų ir kitų želdynų apsaugą (pvz., Florencijos chartija). Tačiau visas šias pozicijas jungia aktyvios, patrauklios ir gyvybingos tiek ekologine, tiek funkcine prasme viešosios erdvès vizija (10 sèkmingos viešosios erdvès bruožų).

Šiuo atveju gudrybės esmè yra suprojektuoti tokius parko "griaučius", kad šie būtų pakankamai tvirti ir pajègtų išlaikyti parko struktūrą ir identitetą, kartu pasižymètų lankstumu bei sugebejjimu prisitaikyti prie kintančių funkcinių ir ekologinių poreikių.

Kadangi parko teritorijos ribos negrị̌ztamai pakeistos (dèl pasikeitusių žemès nuosavybès santykių), būti- na viso parko teritorijos erdvinè koncepcija integruojant naująji sklypą ir jo galimybes į miesto struktūrą. Nagrinejjamoje teritorijoje plètra yra objektyvus, neišvengiamas faktas, todèl neišvengiamai keisis ir nagrinejjamos teritorijos vizualinio vaizdo meninè kokybè.

Teritorijos zonavimas ir su tuo susijusi erdvine jos fragmentacija yra vienas iš pagrindinių urbanizuotų teritorijų planavimo principų. Todèl integruojant esamus ir galimus miesto parko urbanistinio karkaso ir audinio elementus bei formuojant erdvių hierarchiją parko teritorija zonuojama $\mathfrak{i}$ tris aktyvumo zonas. Pagrindinis parko skirstymas zonomis paremtas tiek gamtiniais (augmenija, reljefas), tiek antropogeniniais (infrastruktūra, užstatymas) veiksniais. Aiškiai išskiriamos trys pagrindinès parko zonos su jose užprogramuotomis pagrindinèmis funkcijomis, kurios stiprinamos ir tobulinamos naujai kuriant urbanistinę išraišką (remiantis viešujų erdvių sistema). Taigi vienos zonos yra patrauklesnès ir tinkamesnès tam tikrai veiklai vystyti, o kitos priskiriamos gamtinems, kurios skirtos kompensuoti žmogaus veiklos padariniams, taip siekiama išlaikyti teritorijos „natūralumo“ balansą. Šiame lygmenyje atsiranda ir neformalios bei nomi-
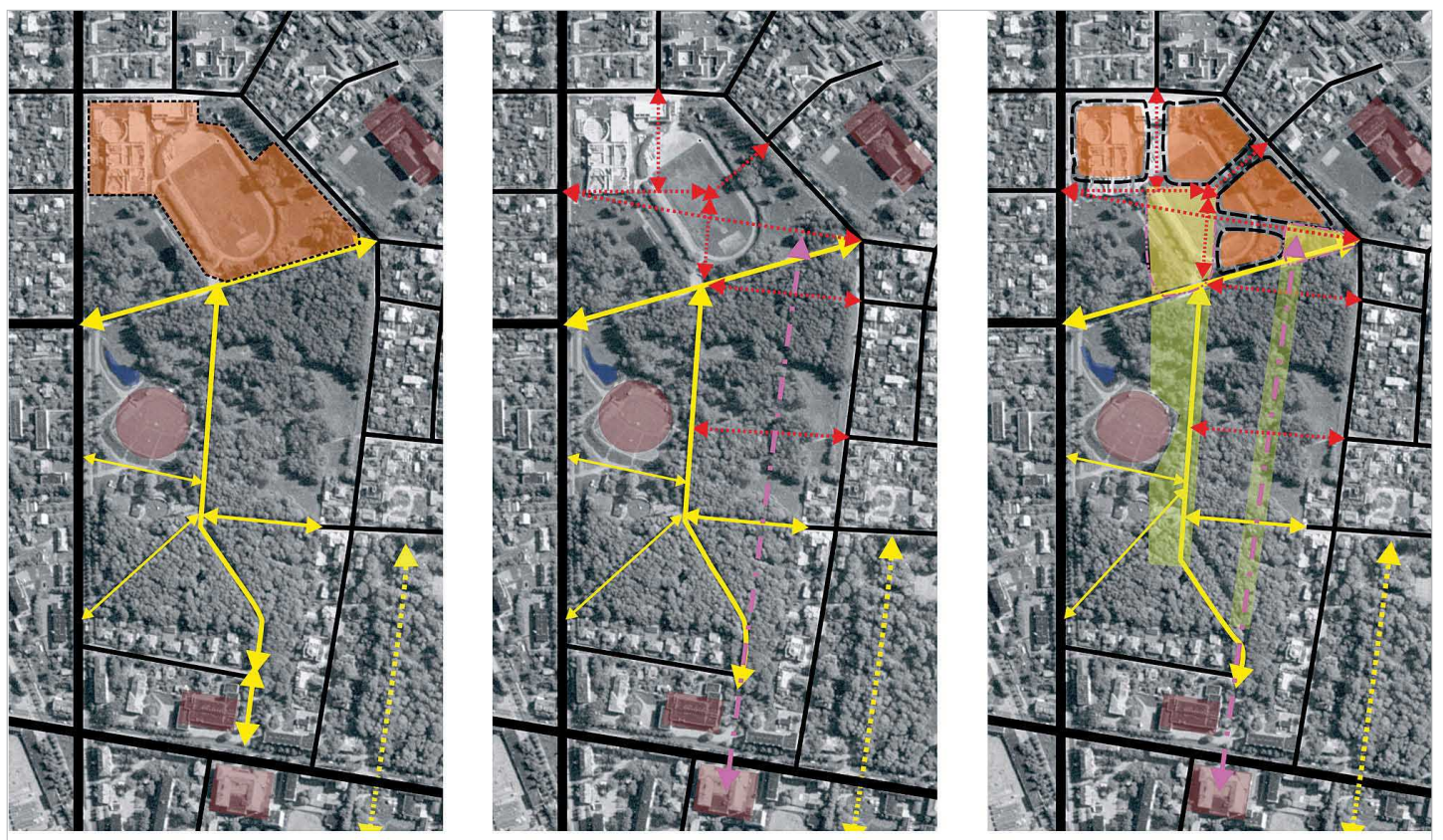

Esamo ir formuojamo urbanistinio karkaso elementy schema

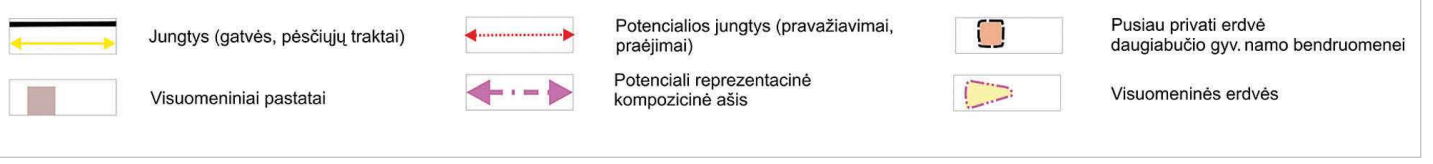

12 pav. Centrinio miesto parko erdvinès ir planinès struktūros tyrimas

Fig. 12. Analysis of spatial and planning structure of central city park 
nalios teritorijos naudojimo zonos galimybès. Todèl iš principo siūlomos dvi principinès parko alternatyvos, nuo kurių priklauso ir nagrinèjamos teritorijos užstatymo architektūrinè urbanistine koncepcija (13 pav):

- dviejų alejų;

- vienos alëjos.

Pasirinkta vienos alëjos parko koncepcija, užtikrinanti nominalių erdvių ịvairovę. Šiuo principu skaidant parko teritoriją nereiktų užmiršti parko prieigose esančių komercinių įstaigų (Vilniaus gatveje), rekreacijos komplekso (dvaro parkas) bei visuomeninių statinių (P. Višinskio biblioteka, Šiaulių kultūros namai, darželis, vidurinè mokykla), kuriems priklausančios parko zonos taip pat gali iggauti išskirtinių bruožų, o tai jas gali paskatinti tapti funkciniu požiūriu autonomiškomis parko dalimis (nes mažesnès struktūrinès dalys kuria parko turinio įvairovę).

Centrinio miesto parko kompozicijoje kaip pagrindiniai formantai pasirinkti vizualinių koridorių ir ašių respektavimas, stiprinimas. Naudojantis šiuo principu gaunama aiški kompozicinè schema. Pagal erdvių sistemos hierarchiją kompozicinejje schemoje aiškiai matosi pagrindinès kompozicinès ašys, kurioms ir galima tai- kyti pagrindines pasirenkamas funkcijas kaip viešųjų erdvių sistemos pagrindą. Dvi pagrindinès kompozicinès ašys galètų tapti reprezentatyviomis viešosiomis erdvèmis, turinčiomis skirtingą turinį, - viena aktyvaus poilsio (nuo sporto ir žaidimų iki viešų akcijų ar stambių koncertų), o kita - kultūrinè (skulptūrų alèja). Plètojant parko funkcijas vadovautasi visuomenès interesu ir vietovès potencialu (t. y. ivvertinta tai, kad kiekviena teritorija turi tam tikrą funkcinio prisotinimo ribą, kurią peržengus prasideda negrižtami teritorijos degradacijos procesai).

Naujai suformuoto sklypo užstatymo koncepcija priklauso nuo užstatymo tipo, kuris glaudžiai susijęs su sklypo dydžiu, nes naujų, ypač labai didelių, sklypų formavimas viršijant tradicinị sklypų mastelį iškreipia teritorijos užstatymo principus, todèl siūlomas šio sklypo struktūrizavimas, paremtas gretimų erdvinių kanalų tąsa. Šiuo atveju parko ribas lemia struktūrinis teritorijos suskaidymas. Projektuojamą kompleksą siūloma traktuoti kaip atskirų korpusų, tarp kurių turi būti išlaikomos bendro naudojimo erdvès (takai, privažiavimai), sistemą (14 pav.).

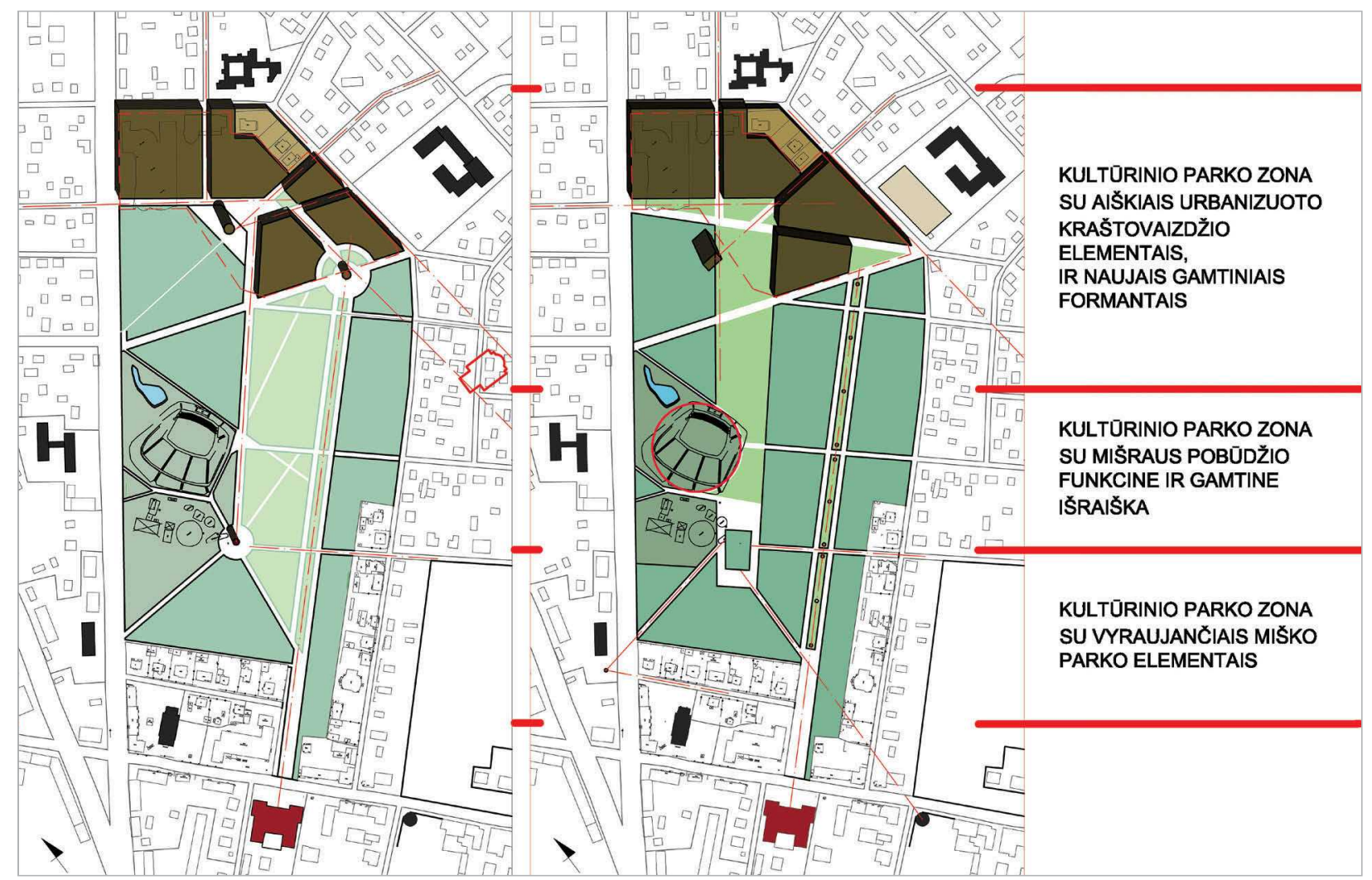

13 pav. Centrinio miesto parko zonavimo schema

Fig. 13. Scheme of zoning of central city park 


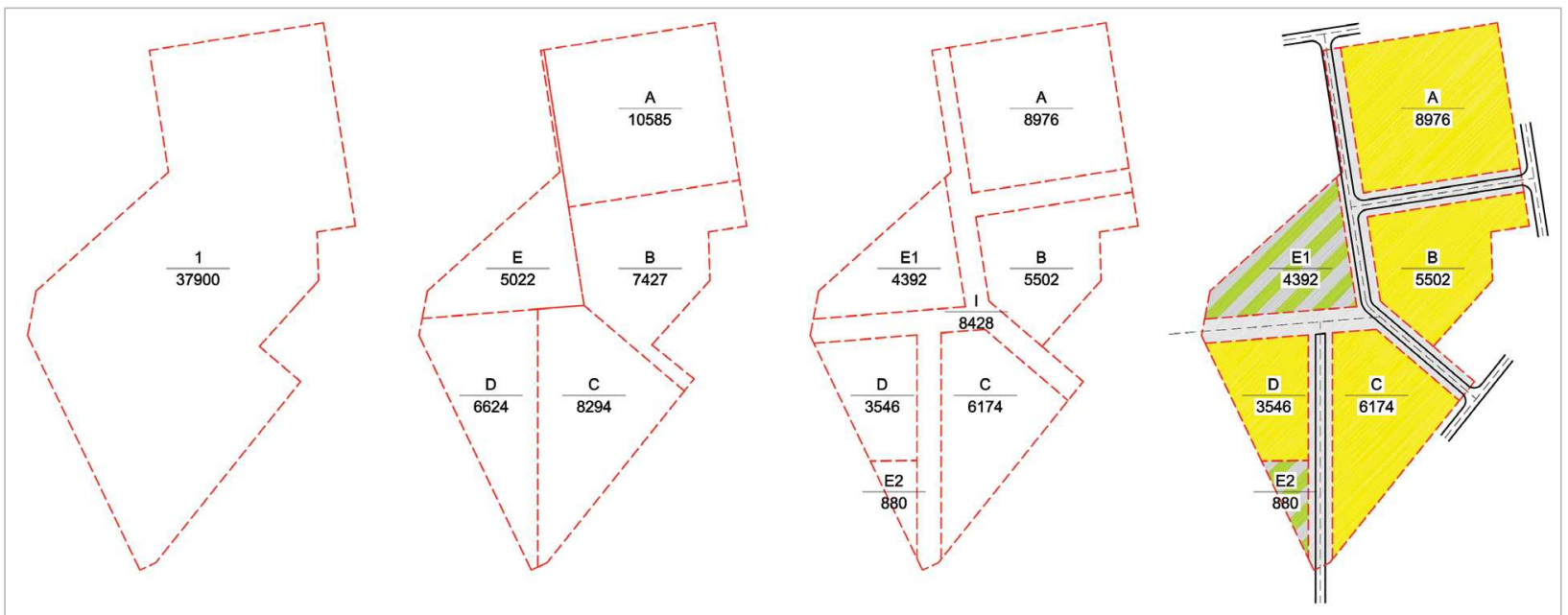

14 pav. Sklypo struktūrizavimas, paremtas gretimu erdvinių kanalų tąsa

Fig. 14. Plot structurization under contiguous spatial channel prolongation

Remiantis nuostata, kad pagrindiné priežastis naujų sklypų formavimas ar atsiradimas viešosiose erdvėse, o urbanizavimo laipsnio nustatymas yra tik to pasekmé, pagal BP plane įrašytą nuostatą suformuotame sklype įmanoma pasiekti 0,8 koeficientą, jei nebūtų plètojama komercinè paskirtis, arba 1,6 koeficientą, jei būtų plètojama komercinè paskirtis. Remiantis skirtingais užstatymo modeliais tokiam pačiam intensyvumui pasiekti (Rogers, Power 2006) formuluojami pagrindiniai užstatymo principai (15 pav.):

- aukštybinis pastatas nèra priimtinas šioje teritorijoje, pagrindinès vertybès jam neleidžia atsirasti, tai miesto katedra;

- sodybinis mažaaukštis šiuo metu yra gretimose teritorijose, ir pagal pagrindinę nuostatą, kad miesto centrinè dalis turi būti intensyviau pletojama, šis užstatymas yra neefektyvus teritorijos naudojimo požiūriu;

- vidutinis aukštingumas yra optimaliausias šioje situacijoje. Pagrindinè sąlyga turi būti mišrios paskirties objektai.

\section{Išvados}

1. Morfologiškai miestų centriniai parkai Lietuvoje daugiausia priskirtini ,apkarpyto kvartalo“ grupei. Situacija tiesiogiai siejama su politine ir ekonomine kryptimi: sovietiniais metais tam tikrų visuomeninių objektų (mokyklų, darželių) statyba parkų prieigose buvo sąmoningas veiksmas planinès ekonomikos sąlygomis, iš dalies nulemtas neprofesionalių

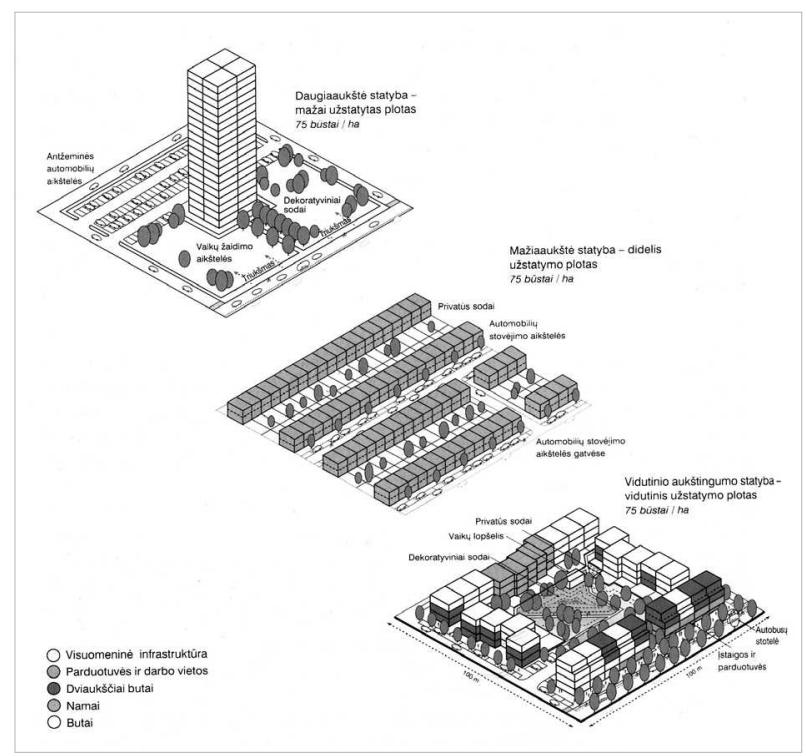

15 pav. Užstatymo intensyvumo galimybès to paties dydžio kvartalui

Fig. 15. Opportunities of buildup intensity for quarter of the same size

sprendimų. Po 1990-ųjų metų žemès grąžinimas bei ịstatymų netobulumas lèmé privataus sektoriaus atsiradimą (daugiausia privačių namų statyba) parko prieigose. Tai iš esmès lemė parko ribų nykimą, todèl naujai reglamentuoti parkų ribas yra neišvengiamas procesas norint užtikrinti tolesnị žaliosios oazès gyvavimą miesto centrinèje dalyje. 
2. Fizinis dydis ne visada siejamas su funkcinių charakteristikų gausa, o labiau su techniniu įrengimo laipsniu. Todèl viena iš priemonių, padedančių organizuoti parko teritoriją ir kartu ją funkciškai isisavinti, yra parko teritorijos zonavimas, kuris taip pat turètų ittakos parko ribų nužymèjimui. Tokiu atveju - kuo didesnè parko teritorija, tuo daugiau tokių zonų joje gali atsirasti, o kartu šios funkcinès zonos gali aptarnauti didesnị kiekį lankytojų arba tenkinti įvairesnius jų poreikius.

3. Tiek Lietuvoje, tiek užsienyje miestų parkų teritorijos mažèja ir yra pamažu urbanizuojamos, todèl iškyla žaliųjų erdvių miestuose fizinių charakteristikų (ploto, planinès konfigūracijos ir kt. savybių) fiksavimo būtinybė. Norint tai atlikti, būtina identifikuoti žaliosios erdvès rangą bendrojoje miesto struktūroje, jos integracijos (funkcinės, infrastruktūrinès, ekologinès ir pan.) laipsnị. Šiaulių centrinis miesto parkas šiuo metu yra vienas iš elementų formuojant ištisinę viešųjų erdvių struktūrą miesto centrinèje dalyje. Jo vaidmuo, modeliuojant Šiaulių miesto ateities scenarijus (intensyvejjant užstatymui, kintant jo kokybei ir pan.), tikètina, tik dar labiau augs.

4. Miesto parko svarbą Šiaulių urbanistinèje struktūroje galima apibūdinti kaip pakankamai reikšmingą, tačiau dabartinè parko situacija yra apgailètina, jo priežiūra ir administravimas yra nepakankami (tam reikia daugiau fizinių ir finansinių pajègumų). Daugumai pavienių iniciatyvų, kuriomis siekiama bent „kosmetiškai“ aptvarkyti parko teritoriją, trūksta sisteminio požiūrio. Kadangi šioje vietoje susikerta labai daug skirtingų interesų, reikia kritiškai ịvertinti atskirus parko raidos etapus ir orientuotis ị šiandieninius parko lankytojų poreikius.

5. Parko plètros principai ir jo formavimo gairè iš dalies priklauso nuo miesto zonos, kurioje parkas yra, taip pat nuo paties parko hierarchijos miesto želdynų sistemoje, nes tik tuomet išryškejja visas galimų teritorijos ateities scenarijų spektras. Generuojant parko scenarijų rekomenduotina surinkti gausų parko teritorijos funkcinio naudojimo idejų banką, kuris galetų remtis tiek retrospektyvine analize, tiek panašių viešųjų erdvių pavyzdžiais, tačiau neperžengti parko prisotinimo ribos rodiklio.

6. Kadangi urbanizaciniai procesai (vykę tiek sovietiniais, tiek nepriklausomybès metais) yra jau įvykęs faktas, todèl tolesnè urbanizacija yra iš principo leistina. Svarbu nustatyti optimalų leistiną urbanizacijos laipsnị. Naujai suformuotas sklypas tiek savo užstatymo kompozicine, tiek funkcine organizacija (kompensuojant prarastas funkcijas) privalo būti integruotas ị bendrą centrinès dalies struktūrą.

7. Naujai suformuoto sklypo užstatymo koncepcija priklauso nuo užstatymo tipo, kuris glaudžiai susijęs su sklypo dydžiu, nes naujų, ypač labai didelių, sklypų formavimas viršijant tradicinị sklypų mastelị iškreipia teritorijos užstatymo principus, todèl siūlomas šio sklypo struktūrizavimas, paremtas gretimų erdvinių kanalų tąsa. Šiuo atveju parko ribas lemia struktūrinis naujai suformuoto sklypo teritorijos suskaidymas. Projektuojamą kompleksą rekomenduojama traktuoti kaip atskirų korpusų, tarp kurių turi būti išlaikomi bendro naudojimo praejimai, sistemą.

\section{Literatūra}

Alistratovaitè, I. 2004. Morfologinès struktūros transformacijos centriniame miesto rajone (Lietuvos pavyzdžiu): daktaro disertacija (humanitariniai mokslai, menotyra $-03 \mathrm{H}$, skulptūra ir architektūra - H312). Vilnius. 242 p.

Alistratovaitė, I.; Stuopelytė, G.; Vyšniūnas, A. (darbo vadovas). 2007a. Teritorijos tarp Žemaités g., Dobilog. ir Centrinio parko Šiauliuose galimybiu studija užstatymo principu ir aukštingumo aspektu. Sutartinis mokslo darbas. Užsakovas „UAB „BALTIC REAL ADVISER“. Vykdytojai - VGTU UK UAML.

Alistratovaitė, I.; Stuopelytė, G., Vyšniūnas, A. (darbo vadovas). 2007b. Vilniaus gatves ir teritorijos prie Vilniaus $g$. Šiauliuose galimybių studija užstatymo principu ir aukštingumo aspektu. Sutartinis mokslo darbas. Užsakovas UAB „Šiaulių titanas“. Vykdytojai - VGTU UK UAML.

Alistratovaitė, I.; Cirtautas, M.; Džervus, P.; Vyšniūnas, A. (darbo vadovas). 2008. Miesto parko ir užstatymo detalizacija. Sutartinis mokslo darbas. Užsakovas - UAB „BALTIC REAL ADVISER“. Vykdytojai - VGTU UK UAML.

Alistratovaitė-Kurtinaitienè, I.; Cirtautas, M.; Džervus, P. 2009. Kürybinès diskusijos „Gargždų miesto parkas ekologiško transporto kontekste", vykusios Gargžduose 2009 m. rugséjo $16-18 d$., ataskaita.

Corner, J. 2007. Introduction, in Czerniak, J.; Hargreaves, G. (Eds.). Large Parks Princeton Architectural Press, 11-31.

Dringelis, L. 2001. Teisiniai ir norminiai dokumentai, reguliuojantys miesto želdynų sistemos planavimą, Urbanistika ir architektūra 25(2): 63-70.

Dringelis, L. 2003. Žemès privatizavimas ir miestų viešojo naudojimo zonų urbanistinis formavimas, Urbanistika ir architektūra 27(4): 163-169.

Dringelis, L. 2005. Miesto želdynų teritorijų klasifikavimas teisinis pagrindas miesto želdynų sistemai planuoti, Urbanistika ir architektūra 29(4): 182-190.

Jakovlevas-Mateckis, K.; Dringelis, L.; Dimindavičiūtė, D. 2007. Lietuvos miestu želdynu urbanistiniu normu sudarymo principai ir pasiūlymai, Urbanistika ir architektūra 31(2): 108-117. 
Krekenavos regioninio tvarkymo planas. 2009. Vilnius. Rengejjas: Všt Gamtos paveldo fondas.

Lietuvos valstybiniu parku ir rezervatu asociacija (LVPRA) [interaktyvus] [žiūrèta $2010 \mathrm{~m}$. rugsèjo 10 d.]. Prieiga per internetą: <http://www.parkai.lt/show/lt/projects.html>.

Peter Walker and Partners [interaktyvus] [žiūrèta $2010 \mathrm{~m}$. spalio 6 d.]. Prieiga per internetą: $<$ http://www.pwpla. com>.

Project for Public Spaces [interaktyvus] [žiūrèta $2010 \mathrm{~m}$. spalio 6 d.]. Prieiga per internetą: $<$ http://www.pps.rog $>$.

Rogers, R.; Power, A. 2006. Mažos valstybès miestai. Vilnius: VDA. 87 p.

Steenbergen, Cl.; Reh, W. 2003. Landscape and architecture. Birkhauser. $400 \mathrm{p}$.

Šiauliu miesto bendrasis planas. Rengimo etapas. II dalis. Sprendiniu konkretizavimas. 2008. UAB „Urbanistika“ [interaktyvus] [žiūrèta $2010 \mathrm{~m}$. rugsèjo 21d.]. Prieiga per internetą: <http://www.siauliai.lt/architektura/bplanas/ Bendrojo\%20plano\%20aiskinamasis\%20rastas.pdf $>$.

Traku istorinio nacionalinio parko ir jo zonu bei buferines apsaugos zonos ribu planas. 2007. Vilnius. Rengejas: VI Valstybinis žemetvarkos institutas, Kraštotvarkos ir teritorijų planavimo skyrius.

\section{A CITY PARK IN STRUCTURAL URBAN DEVELOPMENT (BY THE EXAMPLE OF ŠIAULIAI CITY)}

\section{Alistratovaitè-Kurtinaitienè}

Abstract. Nowadays there is a renewed interest in city parks as recreational oases providing tranquillity and balancing out urban processes. This paper reviews characteristic features of city parks situated in an urban environment, presents comparative characteristics of exceptional parks, and summarizes the development of city parks in Lithuania in the 20th century. Within this context a feasibility study of the central park in Siauliai is presented, focussing on the task of clearly distinguishing the park's borders during its moderate urbanization and preserving the park in the process of integration of its urban neighbourhood, meanwhile improving the park's composition and service infrastructure. The paper analyses the park's territory as an element of urban structure: position within the green city structure and the system of green spaces; arrangement of the green space in the overall city structure (hierarchy of values of urban structure elements), degree of its integration; transformations of the park's territory; analysis of the current situation and suggestions

Keywords: central park of Šiauliai, urban environment, green structure, urban structure, hierarchy of spaces.

\section{INESA ALISTRATOVAITE்- KURTINAITIENE்}

PhD, Assoc. Prof., Dept of Urban Design, Vilnius Gediminas Technical University (VGTU), Pylimo g. 26/Traku g. 1, 01132 Vilnius, Lithuania.E-mail: inesa.al@gmail.com

Teaching: lectures on urban design, urban renewal and computer urban analysis (of GIS base). Publications: author of 10 research papers. Conferences: reports at 12 international and national conferences or seminars. Research interests: urban design and urban planning, urban morphology. Projects: author or co-author of projects in urban design and architecture. 